Research Article

\title{
Mechanisms of Anthracycline-Enhanced Reactive Oxygen Metabolism in Tumor Cells
}

\author{
James H. Doroshow $\mathbb{i D}^{1,2,3}$ \\ ${ }^{1}$ Division of Cancer Treatment and Diagnosis, National Cancer Institute, NIH, Bethesda, MD 20892, USA \\ ${ }^{2}$ Developmental Therapeutics Branch of the Center for Cancer Research, National Cancer Institute, NIH, Bethesda, MD 20892, USA \\ ${ }^{3}$ Department of Medical Oncology and Therapeutics Research, City of Hope Comprehensive Cancer Center, Duarte, CA 91010, USA
}

Correspondence should be addressed to James H. Doroshow; doroshoj@mail.nih.gov

Received 21 September 2019; Accepted 11 November 2019; Published 3 December 2019

Guest Editor: Nagendra K. Kaushik

Copyright ( 2019 James H. Doroshow. This is an open access article distributed under the Creative Commons Attribution License, which permits unrestricted use, distribution, and reproduction in any medium, provided the original work is properly cited.

In this investigation, we examined the effect of anthracycline antibiotics on oxygen radical metabolism in Ehrlich tumor cells. In tumor microsomes and nuclei, doxorubicin increased superoxide anion production in a dose-dependent fashion that appeared to follow saturation kinetics; the apparent $K_{\mathrm{m}}$ and $V_{\max }$ for superoxide formation by these organelles was $124.9 \mu \mathrm{M}$ and $22.6 \mathrm{nmol} / \mathrm{min} / \mathrm{mg}$, and $103.4 \mu \mathrm{M}$ and $4.8 \mathrm{nmol} / \mathrm{min} / \mathrm{mg}$, respectively. In both tumor microsomes and nuclei, superoxide formation required NADPH as a cofactor, was accompanied by the formation of hydrogen peroxide, and resulted from the transfer of electrons from NADPH to the doxorubicin quinone by NADPH:cytochrome P-450 reductase (NADPH:ferricytochrome oxidoreductase, EC 1.6.2.4). Anthracycline antibiotics also significantly enhanced superoxide anion production by tumor mitochondria with an apparent $K_{\mathrm{m}}$ and $V_{\max }$ for doxorubicin of $123.2 \mu \mathrm{M}$ and $14.7 \mathrm{nmol} / \mathrm{min} / \mathrm{mg}$. However, drug-stimulated superoxide production by mitochondria required NADH and was increased by rotenone, suggesting that the proximal portion of the electron transport chain in tumor cells was responsible for reduction of the doxorubicin quinone at this site. The net rate of drug-related oxygen radical production was also determined for intact Ehrlich tumor cells; in this system, treatment with doxorubicin produced a dose-related increase in cyanide-resistant respiration that was enhanced by changes in intracellular reducing equivalents. Finally, we found that in the presence of iron, treatment with doxorubicin significantly increased the production of formaldehyde from dimethyl sulfoxide, an indication that the hydroxyl radical could be produced by intact tumor cells following anthracycline exposure. These experiments suggest that the anthracycline antibiotics are capable of significantly enhancing oxygen radical metabolism in Ehrlich tumor cells at multiple intracellular sites by reactions that could contribute to the cytotoxicity of this class of drugs.

\section{Introduction}

The anthracycline antibiotics, including doxorubicin and daunorubicin, play an important role in the treatment of human leukemias and lymphomas as well as carcinomas of the breast [1]. The major long-term toxicity of anthracycline therapy is a form of cumulative cardiac toxicity that may produce long-lived morbidity, especially in pediatric cancer patients receiving this class of drugs [2]. A substantial body of experimental evidence has been developed suggesting that the cardiac toxicity of the anthracycline antitumor agents may, in part, be related to the generation of strong oxidant species in the heart [3] catalyzed by flavin dehydrogenases present in multiple subcellular compartments [4]. Redox cycling of the anthracycline quinone moiety by complex I of the cardiac electron transport chain [5] can damage intracellular lipid membranes in mitochondria as well as sodium and calcium transporters in the heart [6]. In addition to redox cycling of the quinone functionality of the anthracyclines, doxorubicin may form a potent drug-iron complex that enhances the formation of powerful oxidants with the chemical characteristics of the hydroxyl radical $[7,8]$. In this 
fashion, as well as through interactions with various iron binding proteins, the anthracycline antibiotics may contribute to myocyte toxicity $[9,10]$.

A role for reactive oxygen species (ROS) produced by redox cycling of the anthracycline quinone in tumor cell killing is also supported by several lines of evidence $[11,12]$. These studies include the demonstration by our laboratory that anthracycline-related tumor cell cytotoxicity can be significantly diminished by the administration of reactive oxygen scavengers [13] or by the modification of intracellular antioxidant defenses in vitro and that resistance to tumor cell killing by doxorubicin can be decreased by inhibition of peroxide detoxification [14]. The oxidative metabolism of the anthracyclines has also been demonstrated to occur in vivo; peripheral blood mononuclear cells taken from breast cancer patients treated with doxorubicin reveal the hallmarks of hydroxyl radical damage to DNA in a fashion that is directly related to the length of time during which patients receive the anthracycline [15]. However, unlike studies in the mammalian heart, no comprehensive evaluation of the sites and mechanisms of anthracycline-induced ROS production for mammalian tumor cells has been developed.

Hence, in the current study, we investigated the mechanisms by which anthracycline antibiotics are metabolized to generate ROS in multiple tumor cell compartments, as well as in intact tumor cells. Our results indicate that, in analogy to findings in cardiac subcellular compartments, drugs of the anthracycline class stimulate superoxide anion and hydrogen peroxide production in tumor cell mitochondria, in microsomes, and in the nucleus. Furthermore, in the presence of doxorubicin, extracellular hydrogen peroxide can be quantitated using intact tumor cells. Finally, under appropriate experimental conditions, doxorubicin-induced ROS formation was found to culminate in the production of the hydroxyl radical, or a similar chemical reactant with equivalent oxidizing potency. Thus, drug-related oxygen radical metabolism could pose an important threat to tumor cell integrity by the production of a strong oxidant stress at multiple cellular sites, contributing to cytotoxic membrane injury and DNA damage.

\section{Materials and Methods}

2.1. Materials. Daunorubicin, rubidazone, aclacinomycin A, and 5-iminodaunorubicin were supplied by the Drug Synthesis and Chemistry Branch, Division of Cancer Treatment and Diagnosis, National Cancer Institute, Bethesda, MD. All drugs were reconstituted in sterile water on the day of preparation and were protected from light until used. Doxorubicin hydrochloride, glutathione (reduced form), glutathione reductase type III, sodium azide, bovine albumin (fraction V), xanthine, xanthine oxidase (Grade 1), cytochrome $c$ (type VI from horse heart), EDTA, NADPH type III, NADH Grade III, NADP ${ }^{+}$Grade V, flavin adenine dinucleotide Grade III, flavin mononucleotide, sodium succinate, sucrose, dicumarol, D-mannitol, dimethyl sulfoxide Grade I, EGTA, sodium HEPES, DTNB, rotenone, antimycin A, Triton X-100, urea, sodium benzoate, Tris, and bovine erythrocyte superoxide dismutase (SOD) (2750 units/mg as assayed by the method of McCord and Fridovich [16]) were purchased from Sigma. Methanol (spectral grade), ethyl alcohol (99\% pure), potassium cyanide, sodium acetate, acetic anhydride, ferrous sulfate, ferric chloride, formaldehyde $(37 \% w / v)$, ammonium acetate, acetic acid, and acetylacetone were obtained from Fisher Chemical Co., Fair Lawn, NJ. Chelex 100 resin (100 to 200 mesh, sodium salt) was purchased from Bio-Rad Laboratories, Richmond, Calif. Catalase of analytical grade (65,000 units/mg protein) was purchased from Boehringer Mannheim Biochemicals, Indianapolis, Ind., and was devoid of SOD activity when assayed by the method of McCord and Fridovich [16]. Diethylurea and dimethylthiourea were purchased from Aldrich. Dulbecco's phosphate buffered saline was obtained from Grand Island Biological Co., Grand Island, NY. BCNU was purchased from Bristol-Myers Squibb. All chemicals were obtained at the highest grade available and were used without further purification. Only glass-distilled, deionized water was used in these studies.

2.2. Cell Lines. Ehrlich-Lettré tumor cells (ascitic variant) and P388 leukemia cells were initially obtained from Dr. T. Khwaja of the University of Southern California/Norris Comprehensive Cancer Center and were maintained by weekly passage of one million cells i.p. in $20 \mathrm{~g}$ female Swiss-Webster mice. For experiments examining the effect of anthracyclines on cellular oxygen radical production, tumor cells were harvested 5-6 days after implantation, washed twice in $0.9 \% \mathrm{NaC}$, exposed to hypotonic shock lysis to remove contaminating erythrocytes [17], and resuspended in PBS that had been treated with Chelex 100 resin to remove trace quantities of iron from the reagent grade buffer. Cell viability (routinely >95\%) was confirmed by exclusion of $0.1 \%$ trypan blue dye.

2.3. Preparation of Tumor Cell Organelles. To prepare the microsomal fraction, Ehrlich tumor cells were resuspended in 4 volumes of an iced solution of $230 \mathrm{mM}$ Tris-HC1 $\mathrm{pH} 7.4$, containing $1 \mathrm{mM}$ EDTA. Tumor cells were sonically disrupted on ice for $90 \mathrm{sec}$ with six $15 \mathrm{sec}$ bursts, each separated by a $10 \mathrm{sec}$ cooling period, using a VWR Biosonik IV ultrasonicator at a power output of 90 watts. Tumor cells were homogenized further on ice with a Dounce homogenizer using 15 strokes of the tight-fitting pestle, and the microsomal fraction was then prepared by differential ultracentrifugation using the method of Hinnen et al. [18]. The pellet from the final $65,000 \times \mathrm{x}$ centrifugation step was washed twice and resuspended before use in $150 \mathrm{mM}$ potassium phosphate buffer, $\mathrm{pH} 7.4$, containing $100 \mu \mathrm{M}$ EDTA.

The tumor cell mitochondrial fraction was prepared in 3 volumes of $0.23 \mathrm{M}$ mannitol, $0.07 \mathrm{M}$ sucrose, $5 \mathrm{mM}$ Tris$\mathrm{HC1}$, and $1 \mathrm{mM}$ EDTA, pH7.4 by sonic disruption of cells in mannitol:sucrose:tris:EDTA for $45 \mathrm{sec}$ on ice with subsequent Dounce homogenization as described above. The mitochondrial fraction was then obtained as previously described [19] with resuspension before use in $250 \mathrm{mM}$ sucrose containing $20 \mathrm{mM}$ HEPES, pH 7.

The nuclear fraction was prepared by modification of the method of Mamaril et al. [20]. Cells were washed twice at $4^{\circ} \mathrm{C}$ 
in $50 \mathrm{mM} \mathrm{KC1}$ and $50 \mathrm{mM}$ Tris-HC1, pH7.5, containing $5 \mathrm{mM} \mathrm{MgC1} 1_{2}$ and then resuspended in 6 volumes of iced $10 \mathrm{mM} \mathrm{NaC1}, 10 \mathrm{mM}$ Tris-HC1, $\mathrm{pH} 7.4$, and $1.5 \mathrm{mM}$ $\mathrm{MgC1}_{2}$. Ehrlich cells were then centrifuged at 10,000 x $g$ for $10 \mathrm{~min}$ at $4^{\circ} \mathrm{C}$, resuspended in 8 volumes of the $\mathrm{NaCl}$ :tris: $\mathrm{MgCl}_{2}$ buffer, and disrupted with 15 strokes of the Dounce homogenizer. Cells were homogenized further on ice with several $15 \mathrm{sec}$ bursts of the ultrasonicator. The degree of cell disruption was checked after each sonic burst by phase contrast microscopy; sonication was continued until at least $95 \%$ of the tumor outer membranes had been broken. The cell suspension was then centrifuged at $600 \times \mathrm{g}$ and $4^{\circ} \mathrm{C}$ for $10 \mathrm{~min}$; the supernatant was discarded and the pellet was resuspended in 2 volumes of $220 \mathrm{mM}$ sucrose, $9.4 \mathrm{mM} \mathrm{KH}_{2} \mathrm{PO}_{4}, 12.5 \mathrm{mM} \mathrm{KH_{2 }} \mathrm{PO}_{4}$, $10 \mathrm{mM} \mathrm{MgCl}_{2}, 2 \mathrm{mM}$ EDTA, and $300 \mu \mathrm{M} \mathrm{NaHCO}$, $\mathrm{pH}$ 7.0. The nuclear suspension was freed of excess cytoplasm with 10-20 strokes of the Dounce homogenizer and then added on ice to 7 volumes of $2.3 \mathrm{M}$ sucrose with stirring. The purified nuclear fraction was prepared using a discontinuous sucrose gradient when $1 \mathrm{ml}$ of $2.3 \mathrm{M}$ sucrose solution containing nuclei was underlaid with $2 \mathrm{ml}$ of $2.1 \mathrm{M}$ sucrose and then centrifuged at $4^{\circ} \mathrm{C}$ and $105,000 \mathrm{x} g$ for $20 \mathrm{~min}$. The nuclear layer was resuspended in $250 \mathrm{mM}$ sucrose and $20 \mathrm{mM}$ HEPES, pH 7.4, before use. The nuclear fraction prepared in this manner was examined for contamination by extranuclear membranes by measurement of marker enzymes and by phase contrast microscopy [20]. The Ehrlich tumor nuclei used in this study contained $<10 \%$ of the specific glutamate dehydrogenase and cytochrome oxidase activities of the initial cell homogenate and were essentially free of extranuclear membranes by microscopic methods. The experimental microsomal, mitochondrial, and nuclear fractions were studied on the day of preparation.

2.4. Measurement of Superoxide Anion Production and $N A D(P) H$ Consumption. Superoxide anion production in experimental samples was determined by the rate of SODinhibitable acetylated cytochrome c reduction as previously described [4]. The initial, linear rate of acetylated cytochrome c reduction was determined spectrophotometrically at $550 \mathrm{~nm}$ and $37^{\circ} \mathrm{C}$ in a Gilford spectrophotometer equipped with a circulating water bath. For experiments assessing the effect of DTNB on superoxide production, the sulfhydryl reagent was added to the paired reaction mixtures which were then preincubated for $2 \mathrm{~min}$ at $37^{\circ} \mathrm{C}$ before the addition of NADPH. Preincubation was not performed in experiments examining the effect of other agents on the rate of superoxide formation. Specific conditions for measurement of superoxide production by drug-treated microsomal, mitochondrial, and nuclear fractions have been described in the legends for the appropriate tables.

The effect of anthracycline antibiotics on the oxidation of $\mathrm{NAD}(\mathrm{P}) \mathrm{H}$ by subcellular fractions from Ehrlich cells was determined in triplicate at $37^{\circ} \mathrm{C}$ by the linear decrease in absorbance at $340 \mathrm{~nm}$. NAD $(\mathrm{P}) \mathrm{H}$ consumption was initiated by the addition of the membrane protein and was calculated using an extinction coefficient of $6.22 \mathrm{nM}^{-1} \mathrm{~cm}^{-1}$ [21].
2.5. Measurement of Oxygen Consumption and Hydrogen Peroxide Formation. The rate of oxygen consumption by Ehrlich tumor cells was determined at $37^{\circ} \mathrm{C}$ with a Model 53 oxygen monitoring system (Yellow Springs Instrument Co., Yellow Springs, Ohio). The $3 \mathrm{ml}$ reaction system usually contained $15 \times 10^{6}$ cells and PBS that had been bubbled with air for $30 \mathrm{~min}$ at $37^{\circ}$ before use. When $\mathrm{KCN}$, rotenone, antimycin A, glucose, or BCNU were added to this system, they were preincubated with the cells for $5 \mathrm{~min}$ at $37^{\circ}$. Oxygen consumption by subcellular fractions was determined in a similar fashion after equilibration of the membrane preparation and drugs with the particular buffer used for $4 \mathrm{~min}$ in the reaction vessel; these reactions were initiated by addition of appropriate cofactors, usually $\mathrm{NAD}(\mathrm{P}) \mathrm{H}$. Free radical scavengers, when used, were added to the reaction vessel and equilibrated for $5 \mathrm{~min}$ prior to the addition of the anthracycline antibiotic. The linear rate of oxygen consumption was determined from 10 to $30 \mathrm{~min}$ after drug treatment. Hydrogen peroxide production was quantitated by the release of oxygen into the system as previously described [22] after the addition of $10 \mu \mathrm{l}$ of catalase (4500-9000 units) through the access slot of the oxygen electrode plunger. The rate of oxygen consumption was calculated from a value of $597 \mathrm{nmol}$ for the total dissolved oxygen of the reaction mixture [23].

2.6. Measurement of Hydroxyl Radical Formation. The formation of $\mathrm{OH}$, or an oxidizing species with the chemical reactivity of $\mathrm{OH}$, by permeabilized Ehrlich cells treated with doxorubicin was assessed by measurement of formaldehyde production from dimethyl sulfoxide (DMSO) as described by Klein et al. [24]. The standard reaction mixture contained $100 \mathrm{mM}$ DMSO, $100 \mu \mathrm{M} \mathrm{Na} \mathrm{N}_{4}$ EDTA, $1 \mathrm{mM}$ NADPH, $0.1 \%$ $(v / v)$ Triton $\mathrm{X}-100,1 \times 10^{7} \mathrm{cells} / \mathrm{ml}$, and the indicated amount of doxorubicin in a final volume of $7 \mathrm{ml}$ of PBS at $\mathrm{pH}$ 7.2. Iron-EDTA was added to the reaction systems as a $1: 2$ mixture of freshly prepared ferrous sulfate in aqueous $\mathrm{Na}_{4}$ EDTA. Quantitation of $\mathrm{OH}$ production in this system was undertaken because of our interest in determining whether or not enrichment of flavin dehydrogenase-specific activities by preparation of subcellular fractions was necessary to demonstrate oxy-radical production (other than $\mathrm{O}_{2}$ consumption and $\mathrm{H}_{2} \mathrm{O}_{2}$ formation) by drug-treated tumor cells.

The reaction systems were initiated by the addition of NADPH; they were then mixed vigorously and incubated, usually for $2 \mathrm{hr}$ at $37^{\circ} \mathrm{C}$, in $25 \mathrm{ml}$ polycarbonate flasks in a shaking water bath. The reactions were terminated by the addition of $0.5 \mathrm{ml}$ of ice-cold $17.5 \%(w / v)$ trichloroacetic acid to $1 \mathrm{ml}$ aliquots taken from the standard reaction mixture. Samples were centrifuged at $1000 \times \mathrm{g}$ for $10 \mathrm{~min}$ in the cold; a $1 \mathrm{ml}$ portion of the supernatant was then assayed for formaldehyde $[24,25]$. In brief, $1 \mathrm{ml}$ of a solution containing $2 \mathrm{M}$ ammonium acetate, $50 \mathrm{mM}$ acetic acid, and $20 \mathrm{mM}$ acetylacetone was added to the $1 \mathrm{ml}$ experimental sample; the sample was then mixed, incubated at $37^{\circ} \mathrm{C}$ for $40 \mathrm{~min}$ in a shaking water bath, and assayed for relative formaldehyde concentration at $25^{\circ} \mathrm{C}$ in a $1 \mathrm{ml}$ volume by spectrophotometric measurement at $410 \mathrm{~nm}$. Zero-time samples, as well as 
samples lacking the reduced pyridine nucleotide cofactor, DMSO, or Ehrlich cells were routinely used as the blanks.

Preliminary experiments revealed that in our assay system, doxorubicin itself at a concentration of $300 \mu \mathrm{M}$ did not significantly affect the quantitation of defined amounts of authentic formaldehyde. We also examined the effect of Ehrlich cells on the recovery of formaldehyde added to the experimental reaction mixture. Compared to a cell-free system, we found that over the concentration range from 10 to $70 \mu \mathrm{M}$, the recovery of genuine formaldehyde varied from 100 to $89 \%$ in the presence of $10^{7}$ Ehrlich cells $/ \mathrm{ml}$.

Formaldehyde levels were determined from a calibration curve that was linear at concentrations from 10 to $250 \mu \mathrm{M}$; the calibration curve was routinely prepared in the standard reaction mixture of each experimental condition without cells or doxorubicin and was processed as described above for each set of experimental samples. The lower limit of sensitivity for the detection of formaldehyde in this assay was approximately $10 \mu \mathrm{M}$.

2.7. Enzyme Assays. The NADPH:cytochrome P-450 reductase activity of the tumor microsomal and nuclear fractions was measured by a technique described previously [4] using nonacetylated cytochrome $\mathrm{c}$ as the electron acceptor. To assess the effect of DTNB $(100 \mu \mathrm{M})$ and $\mathrm{NADP}^{+}(1 \mathrm{mM})$ on NADPH:cytochrome $\mathrm{P}-450$ reductase activity, these reagents were preincubated with the fraction for $2 \mathrm{~min}$ before the addition of NADPH. Glutathione peroxidase activity was determined in tumor cell subcellular fractions as described previously [26] except that enzyme assays were initiated with 440 rather than $220 \mathrm{nmol}$ hydrogen peroxide in these experiments. The data have been expressed as nmol NADPH oxidized to $\mathrm{NAPD}^{+}$per min mg protein. SOD levels were determined in the microsomal, mitochondrial, and nuclear fractions using the xanthine:xanthine oxidase:cytochrome $c$ assay as reported previously [26]. In these experiments, acetylated cytochrome $\mathrm{c}(11.2 \mu \mathrm{M})$ was utilized in addition to $\mathrm{KCN}(10 \mu \mathrm{M})$ to eliminate interference from cytochrome oxidases in the experimental samples.

2.8. Protein Determination. Protein concentrations in subcellular fractions were determined by the method of Lowry et al. [27] using crystalline bovine albumin as the standard.

2.9. Statistical Methods. Data were analyzed with the 2-tailed $t$ test for independent means (not significant, $P>0.05$ [28]).

\section{Results}

3.1. Tumor Microsomes. As shown in Table 1, treatment with doxorubicin increased microsomal superoxide production in a dose-dependent fashion that appeared to conform to saturation kinetics. Furthermore, a doxorubicin concentration as low as $5 \mu \mathrm{M}$ significantly increased oxy-radical formation over control levels (data not shown). In these experiments, superoxide production varied with the amount of microsomal protein used. In the absence of doxorubicin, superoxide formation was (mean \pm S.E.; $n=3$ ) $0.42 \pm 0.10$ and $0.96 \pm 0.20 \mathrm{nmol} / \mathrm{min}$ with 100 and $400 \mu \mathrm{g}$ protein $/ \mathrm{ml}$, respectively; in the presence of doxorubicin (135 $\mu \mathrm{M})$, super-
TABLE 1: Kinetic constants for superoxide production by Ehrlich tumor subcellular fractions after treatment with doxorubicin. Superoxide production by tumor microsomes, mitochondria, and nuclei was assayed as described in Tables 2, 6, and 7. Kinetic constants were determined in triplicate to form the direct equation relating reaction velocity to substrate concentration as described in [48] using 8 different drug concentrations over a 10-fold concentration range.

\begin{tabular}{lcc}
\hline \multirow{2}{*}{ Subcellular fraction } & \multicolumn{2}{c}{ Superoxide formation } \\
& $K_{\mathrm{m}}(\mu \mathrm{M})$ & $V_{\max }(\mathrm{nmol} / \mathrm{min} / \mathrm{mg})$ \\
\hline Microsomes & 124.9 & 22.6 \\
Mitochondria & 123.2 & 14.7 \\
Nuclei & 103.4 & 4.8 \\
\hline
\end{tabular}

oxide production was $1.73 \pm 0.07$ and $3.14 \pm 0.08 \mathrm{nmol} / \mathrm{min}$, $P<0.01$ for each compared to control. As shown in Table 2, all components of the reaction system, including NADPH, intact microsomes, and acetylated cytochrome $\mathrm{c}$ were necessary to demonstrate a significant increase in superoxide formation by doxorubicin. Furthermore, only NADPH, of a variety of cofactors, could support drug-related superoxide production in these studies (Table 2).

The specificity of our assay for drug-stimulated superoxide production was also addressed (Table 2). We found that SOD-inhibitable cytochrome $\mathrm{c}$ reduction was not affected by catalase or DMSO in concentrations capable of eliminating either $\mathrm{H}_{2} \mathrm{O}_{2}$ or the hydroxyl radical from the reaction system (Table 2). The addition of heat-denatured SOD to the experimental system also produced no significant change in the rate of drug-stimulated superoxide production. These experiments suggest that superoxide was, in fact, measured in our studies.

As shown in Table 3, three of the four anthracycline antibiotics tested in addition to doxorubicin significantly increased microsomal superoxide production over control levels. However, 5-iminodaunorubicin, an anthracycline ana$\log$ that has been previously demonstrated under other conditions to be incapable of redox cycling because of its substituted quinone ring [4], did not stimulate superoxide production by the tumor microsomal fraction.

To define the mechanism of oxygen radical production by anthracycline-treated microsomes, we measured the rate of NADPH consumption in tumor microsomes after treatment with doxorubicin. In the presence of $100 \mu \mathrm{M}$ $\mathrm{NADPH}$ and $100 \mu \mathrm{g} / \mathrm{ml}$ of microsomal protein from tumor, the control rate of NADPH oxidation was $7.00 \pm$ $0.81 \mathrm{nmol} / \mathrm{min} / \mathrm{mg}, \quad n=4$; the addition of doxorubicin $(135 \mu \mathrm{M})$ increased the rate of NADPH oxidation to $19.90 \pm 2.30 \mathrm{nmol} / \mathrm{min} / \mathrm{mg}, n=4, P<0.01$. Furthermore, we found that the tumor microsomal fraction contained a substantial level of NADPH:cytochrome P-450 reductase activity (Table 4). After treatment of microsomes with the enzyme inhibitors DTNB or excess $\mathrm{NADP}^{+}$, enzyme activity decreased to 27.7 or $23.2 \%$ of control levels, $P<0.01$ for both agents (Table 4). In parallel experiments, DTNB or excess $\mathrm{NADP}^{+}$decreased drug-related superoxide production to 41.3 or $26.6 \%$ of baseline levels, $P<0.01$ for each inhibitor (Table 4). Finally, we found that the inhibitor of 
TABLE 2: Requirements for doxorubicin-stimulated superoxide formation in the tumor microsomal fraction. Superoxide production in tumor microsomes was determined in paired, $1 \mathrm{ml}$ reaction mixtures which contained $150 \mathrm{mM}$ potassium phosphate buffer, $\mathrm{pH} 7.4,100 \mu \mathrm{M}$ EDTA, $56 \mu \mathrm{M}$ acetylated cytochrome c, $200 \mu \mathrm{g}$ of microsomal protein, and either 0 or $10 \mu \mathrm{g}$ of SOD. The chemotherapeutic agent was added to the paired reaction mixtures, where specified, before the initiation of the reaction by addition of NADPH (1 mM).

\begin{tabular}{|c|c|}
\hline Experimental system & $\begin{array}{c}\text { Superoxide production } \\
\text { nmol cytochrome c } \\
\text { reduced } / \mathrm{min} / \mathrm{mg}\end{array}$ \\
\hline Control & $0.51 \pm 0.26(3)^{\mathrm{a}}$ \\
\hline -Microsomes & N.D. $(3)^{b}$ \\
\hline -NADPH & N.D. (3) \\
\hline -Cytochrome c & N.D. (3) \\
\hline Using NADPH $(100 \mu \mathrm{M})$ & N.D. (3) \\
\hline $\begin{array}{l}\text { Using NADH }(1 \mathrm{mM}) \\
\text { rather than NADPH }\end{array}$ & $0.97 \pm 0.28(3)$ \\
\hline Doxorubicin $(135 \mu \mathrm{M})$ & $14.71 \pm 1.43(6)^{\mathrm{c}}$ \\
\hline -Microsomes & N.D. $(3)^{\mathrm{d}}$ \\
\hline -NADPH & N.D. $(3)^{\mathrm{d}}$ \\
\hline -Cytochrome c & N.D. $(3)^{\mathrm{d}}$ \\
\hline Using heat-denatured microsomes ${ }^{\mathrm{e}}$ & N.D. $(3)^{\mathrm{d}}$ \\
\hline Using heat-denatured $\mathrm{SOD}^{\mathrm{e}}$ & $13.77 \pm 0.37(3)$ \\
\hline Using NADPH $(100 \mu \mathrm{M})$ & $10.07 \pm 0.82(6)$ \\
\hline $\begin{array}{l}\text { Using NADH }(1 \mathrm{mM}) \text { rather than } \\
\text { NADPH }\end{array}$ & $2.81 \pm 0.56(3)^{\mathrm{d}}$ \\
\hline $\begin{array}{l}\text { Using NADP }{ }^{+}(1 \mathrm{mM}) \text { rather than } \\
\text { NADPH }\end{array}$ & $1.35 \pm 0.26(3)^{\mathrm{d}}$ \\
\hline $\begin{array}{l}\text { Using NAD }{ }^{+}(1 \mathrm{mM}) \text { rather than } \\
\text { NADPH }\end{array}$ & $0.36 \pm 0.26(3)^{\mathrm{d}}$ \\
\hline $\begin{array}{l}\text { Using FAD }(1 \mathrm{mM})^{\mathrm{f}} \text { rather than } \\
\text { NADPH }\end{array}$ & $0.49 \pm 0.49(3)^{\mathrm{d}}$ \\
\hline Using FMN $(1 \mathrm{mM})^{\mathrm{f}}$ & N.D. $(3)^{\mathrm{d}}$ \\
\hline +DMSO (13 mM) & $16.32 \pm 0.51(3)$ \\
\hline +Catalase (1500 units) & $14.36 \pm 0.08(3)$ \\
\hline +Dicumarol $(10 \mu \mathrm{M})$ & $14.41 \pm 1.91(3)$ \\
\hline
\end{tabular}

${ }^{a}$ Mean \pm S.E.; number in parentheses is number of experiments performed; ${ }^{b}$ N.D. is not detectable; ${ }^{c}$ significantly different from control $(P<0.001)$;

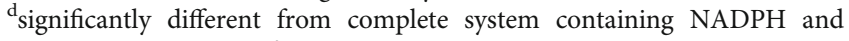
doxorubicin $(P<0.01)$; ${ }^{\mathrm{e}}$ microsomes or SOD heated for $60 \mathrm{~min}$ in a boiling water bath; samples containing heat-denatured SOD were paired against identical mixtures with native dismutase; ${ }^{\mathrm{f}} \mathrm{FAD}$ : flavin adenine dinucleotide; FMN: flavin mononucleotide.

NADPH:quinone oxidoreductase 1, dicumarol, produced no significant effect on doxorubicin-stimulated superoxide production (Table 2), suggesting that this quinone reductase is not involved in the metabolism of anthracyclines by tumor microsomes. Taken together, these experiments strongly suggest that the NADPH:cytochrome P-450 reductase activity of the Ehrlich tumor microsomal fraction is responsible for the one-electron reduction of anthracycline antibiotics at this site.

To confirm that anthracycline antibiotics increased reactive oxygen production in tumor microsomes, we
TABLE 3: Effect of anthracycline antibiotics on superoxide production by the tumor microsomal fraction. Superoxide production in tumor microsomes was determined as described in Table 2. For these studies, all drugs were present at a concentration of $135 \mu \mathrm{M}$.

\begin{tabular}{lc}
\hline Drug & Superoxide formation $(\mathrm{nmol} / \mathrm{min} / \mathrm{mg})$ \\
\hline Daunorubicin & $10.00 \pm 1.02(5)^{\mathrm{a}, \mathrm{b}}$ \\
Rubidazone & $6.66 \pm 0.84(6)^{\mathrm{b}}$ \\
Aclacinomycin A & $16.14 \pm 0.85(3)^{\mathrm{b}}$ \\
5-Iminodaunorubicin & $0.45 \pm 0.15(3)$ \\
\hline
\end{tabular}

${ }^{\mathrm{a}}$ Mean \pm S.E.; number in parentheses is number of experiments performed; $\mathrm{b}$ significantly higher than the control rate of superoxide formation in tumor microsomes $(P<0.01$; Table 2$)$

examined the effect of doxorubicin on microsomal oxygen consumption. As demonstrated in Supplementary Table 1, oxygen consumption increased more than 6-fold in the presence of doxorubicin, $P<0.001$. Drug-stimulated oxygen consumption was significantly inhibited by cytochrome $c$ which reacts directly with superoxide to return oxygen to this closed system and was significantly increased by $\mathrm{KCN}$, probably because of the inhibition of microsomal SOD (Table 5). As shown in Figure 1(a), we found that oxygen was released routinely by addition of excess catalase to microsomes treated with doxorubicin, indicating that $\mathrm{H}_{2} \mathrm{O}_{2}$ as well as superoxide anion had been produced in these investigations. We found that $\mathrm{H}_{2} \mathrm{O}_{2}$ production increased from undetectable control levels $(n=3)$ to $3.42 \pm 0.48 \mathrm{nmol} / \mathrm{min} / \mathrm{mg}(n=4 ; P<0.01)$ after treatment of the microsomal fraction with doxorubicin $(135 \mu \mathrm{M})$. Thus, NADPH-dependent microsomal metabolism of doxorubicin results in both superoxide anion and $\mathrm{H}_{2} \mathrm{O}_{2}$ formation.

3.2. Tumor Mitochondria. Because previous studies in cardiac tissue had indicated that the electron transport chain could reduce doxorubicin to its semiquinone [4], we examined the effect of doxorubicin on reactive oxygen formation by the Ehrlich tumor mitochondrial fraction. We found that for tumor mitochondria, as well as microsomes, treatment with doxorubicin increased superoxide formation in a dosedependent fashion that also appeared to follow saturation kinetics (Table 1). However, in mitochondria, superoxide production was NADH- rather than NADPH-dependent and was significantly increased by addition of rotenone to block electron flow beyond complex I of the electron transport chain (Table 6). Furthermore, substituting $\mathrm{NAD}^{+}$ $(100 \mu \mathrm{M}), \mathrm{NADP}^{+}(100 \mu \mathrm{M})$, or succinate $(1 \mathrm{mM})$ for $\mathrm{NADH}$ yielded no detectable drug-enhanced superoxide production by tumor mitochondria (data not shown).

Superoxide production in the mitochondrial fraction after treatment with doxorubicin $(135 \mu \mathrm{M})$ increased from $(n=3) 0.37 \pm 0.03$ to $0.76 \pm 0.02$ and $1.05 \pm 0.07 \mathrm{nmol} / \mathrm{min}$ when 50,150 , or $200 \mu \mathrm{g} / \mathrm{ml}$ of mitochondrial protein was employed. In contrast, superoxide production by tumor mitochondria in the absence of doxorubicin was $0.10 \pm 0.04$, $0.18 \pm 0.05$, and $0.21 \pm 0.03 \mathrm{nmol} / \mathrm{min}$ for the identical levels of mitochondrial protein, $P<0.01$ for each drug-treated 
TABle 4: Effect of inhibitors of NADPH:cytochrome p-450 reductase on superoxide formation in tumor microsomes. NADPH:cytochrome P-450 reductase was assayed at $30^{\circ} \mathrm{C}$ as described in Materials and Methods using nonacetylated cytochrome $\mathrm{c}$ and $200 \mu \mathrm{g}$ of microsomal protein per ml. Reactions were initiated with $100 \mathrm{nmol}$ of NADPH. Where indicated, the reaction mixtures were preincubated with $\mathrm{DTNB}$ or $\mathrm{NADP}^{+}$for $2 \mathrm{~min}$ prior to the initiation of cytochrome $\mathrm{c}$ reduction. In these experiments, superoxide production was assessed as described in Table 2 except that the NADPH concentration was $100 \mu \mathrm{M}$ rather than $1 \mathrm{mM}$.

\begin{tabular}{ccc}
\hline Experimental system & $\begin{array}{c}\text { NADPH:cytochrome } \\
\text { P-450 reductase activity } \\
(\mathrm{nmol} / \mathrm{min} / \mathrm{mg})\end{array}$ & $\begin{array}{c}\text { Superoxide } \\
\text { production } \\
(\mathrm{nmol} / \mathrm{min} / \mathrm{mg})\end{array}$ \\
\hline Control & $233.5 \pm 12.5(3)^{\mathrm{a}}$ & \\
+DTNB $(100 \mu \mathrm{M})$ & $54.1 \pm 1.6(3)^{\mathrm{b}}$ & \\
+NADP $(1 \mathrm{mM})$ & $64.6 \pm 1.5(3)^{\mathrm{b}}$ & \\
Doxorubicin $(135 \mu \mathrm{M})$ & & $10.1 \pm 1.0(3)$ \\
+DTNB $(100 \mu \mathrm{M})$ & & $4.2 \pm 0.4(3)^{\mathrm{b}}$ \\
+NADP $(1 \mathrm{mM})$ & & $2.7 \pm 0.2(3)^{\mathrm{b}}$ \\
\hline
\end{tabular}

${ }^{a}$ Mean \pm S.E.; numbers in parentheses are numbers of experiments;

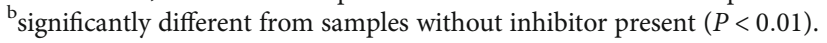

Table 5: Antioxidant enzyme levels in tumor subcellular fractions. Ehrlich tumor microsomes, mitochondria, and nuclei were prepared and assayed for glutathione peroxidase and SOD activity as described in Materials and Methods. The "cytosol" fraction was the supernatant from the final $65,000 \times \mathrm{g}$ centrifugation step used in the preparation of the microsomal fraction. Before determination of enzyme activity, the mitochondrial fraction was exposed to ultrasonic disruption on ice with 4 bursts of $15 \mathrm{sec}$ each at 90 watts output to eliminate permeability barriers to appropriate substrates in these assays. The supernatant and pellet resulting from centrifugation of the sonicated mitochondria at $105,000 \times \mathrm{g}$ and $4^{\circ} \mathrm{C}$ for $60 \mathrm{~min}$ were also assayed from enzyme activities.

\begin{tabular}{lcc}
\hline Tumor cell fraction & $\begin{array}{c}\text { Glutathione } \\
\text { peroxidase }(\mathrm{nmol} / \mathrm{min} / \mathrm{mg})\end{array}$ & $\begin{array}{c}\text { SOD } \\
(\mu \mathrm{g} \mathrm{SOD} / \mathrm{mg})\end{array}$ \\
\hline Cytosol & $211.6 \pm 11.0(4)^{\mathrm{a}}$ & $8.1 \pm 0.8(3)$ \\
Microsomes & $22.5 \pm 1.6(4)$ & $1.4 \pm 0.3(3)$ \\
Nuclei & $10.1 \pm 2.2(3)$ & $0.5 \pm 0.1(3)$ \\
Mitochondria & $55.5 \pm 8.0(3)$ & $5.6 \pm 0.3(3)$ \\
$\quad \begin{array}{l}105,000 \times \mathrm{g} \\
\text { supernatant }\end{array}$ & $197.9 \pm 20.9(3)$ & $3.2 \pm 0.4(3)$ \\
$105,000 \mathrm{x}$ g pellet & N.D. $(3)^{\mathrm{b}}$ & $1.6 \pm 0.2(3)$ \\
\hline
\end{tabular}

${ }^{\mathrm{a}}$ Mean \pm S.E.; numbers in parentheses are numbers of experiments; ${ }^{\mathrm{b}}$ N.D. is not detectable.

sample compared to control. We also found that the anthracycline antibiotics which had significantly enhanced microsomal superoxide production also increased mitochondrial oxy-radical formation (Table 6). Finally, we found that doxorubicin $(135 \mu \mathrm{M})$ stimulated the rate of NADH oxidation by tumor mitochondria $(100 \mu \mathrm{g} / \mathrm{ml})$ in the presence of rotenone from $4.70 \pm 0.42(n=3)$ to $9.74 \pm 0.63(n=3) \mathrm{nmol} / \mathrm{min} / \mathrm{mg}$, $P<0.01$. Thus, it is likely that an early portion of the NADH dehydrogenase complex is responsible for the reduction of anthracycline antibiotics to free radicals in tumor mitochondria.

To investigate the effect of doxorubicin on mitochondrial reactive oxygen metabolism further, the rate of oxygen consumption by drug-treated mitochondria was examined. As shown in Supplementary Table 2, doxorubicin significantly increased the rate of mitochondrial oxygen consumption; furthermore, the rate of drug-stimulated oxygen consumption was not affected by $\mathrm{KCN}$ or dicumarol, suggesting that (1) mitochondrial SOD in Ehrlich tumor cells is not inhibited by cyanide and that (2) NADPH:quinone oxidoreductase 1 does not appear to be involved in the free radical metabolism of doxorubicin in tumor mitochondria. On the other hand, drug-stimulated oxygen consumption was decreased to control levels in the presence of acetylated cytochrome $c$ suggesting that most, if not all, of the oxygen consumed had at least initially been converted to superoxide anion (Supplementary Table 2). We also found (Figure 1(b)) that treatment with doxorubicin increased mitochondrial $\mathrm{H}_{2} \mathrm{O}_{2}$ production from undetectable control levels $(n=3)$ to $2.6 \pm$ $0.6 \mathrm{nmol} / \mathrm{min} / \mathrm{mg}, n=3, P<0.01$. Thus, exposure of tumor mitochondria, as well as microsomes, to doxorubicin increases both superoxide anion and hydrogen peroxide production.

3.3. Tumor Nuclei. Treatment of Ehrlich tumor nuclei with doxorubicin significantly increased superoxide production (Table 7). In this organelle, oxy-radical formation required intact nuclear protein and NADPH; neither NADH, FAD, nor FMN could support drug-stimulated nuclear superoxide formation. Furthermore, daunorubicin, rubidazone, and aclacinomycin A all significantly increased reactive oxygen metabolism compared to control (Table 7). As shown in Table 1, superoxide production in the nuclear fraction also appeared to follow saturation kinetics. We found that doxorubicin $(135 \mu \mathrm{M})$ increased the rate of NADPH $(100 \mu \mathrm{M})$ oxidation by the nuclear fraction $(200 \mu \mathrm{g}$ protein $/ \mathrm{ml})$ from a control rate of $2.20 \pm 0.31 \quad(n=3)$ to $11.11 \pm 0.73 \mathrm{nmol} / \mathrm{min} / \mathrm{mg}, n=3, P<0.01$.

As shown in Supplementary Table 3, Ehrlich tumor nuclei possessed approximately $2 \%$ of the NADPH:cytochrome P450 reductase activity of the microsomal fraction. This enzymatic activity could be inhibited by excess $\mathrm{NADP}^{+}$and could be removed completely by treatment of the nuclear fraction with a nonionic detergent capable of stripping the outer nuclear envelope from underlying DNA and chromatin. In related experiments, we found that doxorubicin-stimulated nuclear superoxide formation could also be significantly inhibited or abolished by treatment of the nuclei with the detergent (Supplementary Table 3). These experiments strongly suggest that NADPH:cytochrome P-450 reductase activity normally associated with the outer nuclear envelope is responsible for activating doxorubicin to its free radical at that locale.

In analogy to our microsomal and mitochondrial experiments, we investigated nuclear oxygen consumption in the presence of doxorubicin. In this setting, control nuclei 


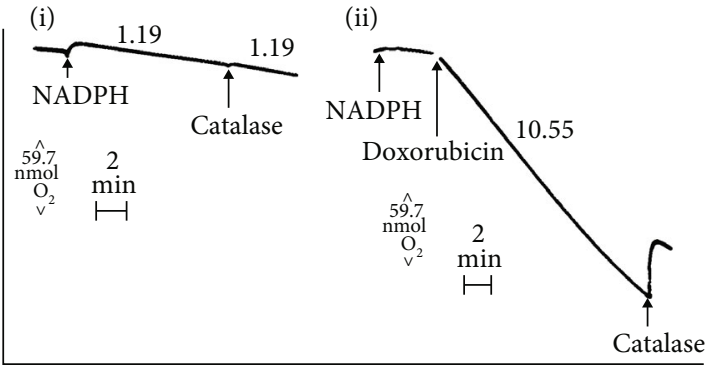

(a)

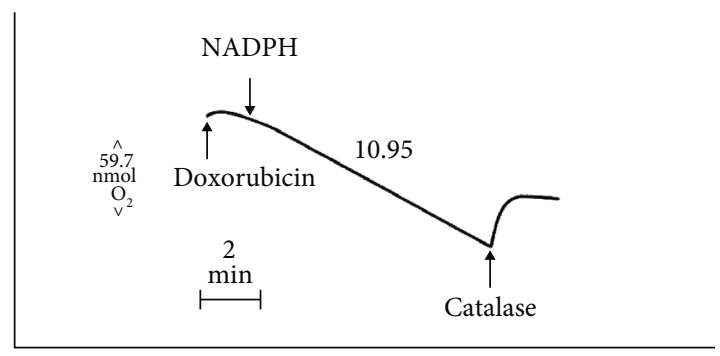

(c)

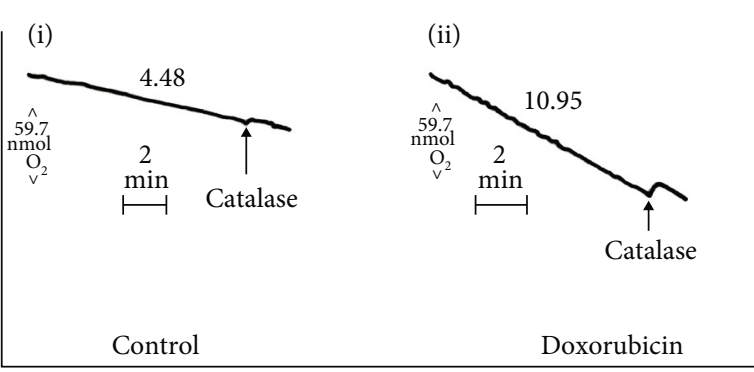

(b)

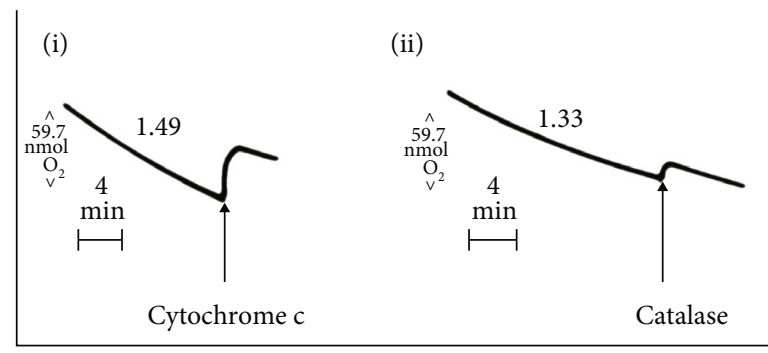

(d)

Figure 1: Effect of doxorubicin on oxygen consumption by Ehrlich tumor organelles. Oxygen consumption in tumor microsomes was examined as described in Supplementary Table 1. (a, i) is without drug; (ii) shows the results with doxorubicin. The addition of NADPH $(1 \mathrm{mM})$, catalase (4500 units), or doxorubicin $(135 \mu \mathrm{M})$ to the $3 \mathrm{ml}$ vessel was performed through the access slot of the oxygen electrode and has been indicated (arrow). The numbers above each tracing indicate the rate of oxygen consumption (nmol/min/mg). (b) Effect of doxorubicin on oxygen consumption by Ehrlich tumor mitochondria. Oxygen consumption in these representative experiments was performed as described in Supplementary Table 2. (i) is the control reaction; (ii) represents the identical experiment in the presence of doxorubicin $(135 \mu \mathrm{M})$. The addition of catalase (4500 units) to the $3 \mathrm{ml}$ vessel was performed through the access slot of the oxygen electrode and has been indicated by the arrow. The numbers above each tracing indicate the rate of oxygen consumption (nmol/min/mg). (c) Effect of doxorubicin on oxygen consumption by Ehrlich tumor nuclei. Experimental conditions consisted of a $3 \mathrm{ml}$ system containing $250 \mathrm{mM}$ sucrose, $20 \mathrm{mM}$ HEPES, pH 7.4, $100 \mu \mathrm{M}$ EDTA, $1 \mathrm{mM} \mathrm{NADPH}$, and $200 \mu \mathrm{g} / \mathrm{ml}$ of nuclear protein at $37^{\circ} \mathrm{C}$. The addition of $\mathrm{NADPH}(1 \mathrm{mM})$, doxorubicin $(135 \mu \mathrm{M})$, or catalase (4500 units) to the $3 \mathrm{ml}$ reaction vessel was performed through the access slot of the oxygen electrode and has been indicated by an arrow. The number above the tracing is the rate of oxygen consumption (nmol/min/mg). (d) Doxorubicin-stimulated oxygen consumption by Ehrlich tumor cells. The effect of doxorubicin (400 $\mu \mathrm{M})$ on oxygen consumption by Ehrlich cells $\left(5 \times 10^{6}\right.$ cells $\left./ \mathrm{ml}\right)$ is shown in representative examples from multiple experiments. The addition of acetylated cytochrome c $(168 \mathrm{nmol})$ in (i) or catalase (9000 units) in (ii) to the $3 \mathrm{ml}$ vessel has been indicated by an arrow. The numbers above each tracing indicate the rate of oxygen consumption $(\mathrm{nmol} / \mathrm{min} / \mathrm{ml})$.

consumed $0.93 \pm 0.12 \mathrm{nmol} \mathrm{O} / \mathrm{min} / \mathrm{mg}, n=3$. Oxygen consumption increased 10 -fold in the presence of doxorubicin $(135 \mu \mathrm{M})$ to $9.45 \pm 0.89 \mathrm{nmol} / \mathrm{min} / \mathrm{mg}, \quad n=6, \quad P<0.01$. Treatment with $\mathrm{KCN}(1 \mathrm{mM})$ did not increase drugstimulated oxygen consumption significantly $(11.04 \pm 0.80$ $\mathrm{nmol} / \mathrm{min} / \mathrm{mg}, n=4)$, probably because of the small amount of SOD associated with the nuclear fraction (Table 5). However, the addition of acetylated cytochrome $c(56 \mu \mathrm{M})$ decreased oxygen consumption to $2.09 \pm 0.26 \mathrm{nmol} /-$ $\mathrm{min} / \mathrm{mg}, n=3, P<0.01$ compared to samples containing doxorubicin alone. Thus, most of the oxygen consumed had probably been reduced, at least initially, to superoxide anion. As shown in Figure 1(c), drug-enhanced oxygen consumption required NADPH and was associated with the production of $\mathrm{H}_{2} \mathrm{O}_{2}$. In these studies, drug treatment $(135 \mu \mathrm{M})$ increased $\mathrm{H}_{2} \mathrm{O}_{2}$ formation from undetectable control levels $(n=3)$ to $5.2 \pm 1.3 \mathrm{nmol} / \mathrm{min} / \mathrm{mg}, n=3, P<0.01$.

3.4. Whole Tumor Cells. To examine the net effect of anthracycline antibiotics on oxy-radical production by Ehrlich tumor, we investigated whether doxorubicin altered the respiratory rate of intact tumor cells. Treatment with doxoru- bicin significantly increased the rate of oxygen consumption by tumor cells in which the electron transport chain had been blocked by either cyanide or antimycin A (Table 8) [29, 30]. It is likely that the magnitude of the overall rate of mitochondrial $\mathrm{O}_{2}$ consumption in tumor cells makes the smaller, drug-related effects impossible to detect in the absence of respiratory chain blockade. We found that the increase in respiratory rate was drug-dose dependent and was found for daunorubicin as well as doxorubicin; however, the daunorubicin analog 5-iminodaunorubicin which has a blocked quinone group that does not permit redox cycling did not enhance cyanide-resistant respiration by Ehrlich cells [31, 32]. In control experiments, we found that tumor cell viability in the presence of $\mathrm{KCN}$ as measured by exclusion of trypan blue dye did not decline significantly over the reaction period of these studies. Furthermore, the addition of glucose to the cells, which produces an increase in intracellular NADPH concentration [22], significantly increased the rate of $\mathrm{O}_{2}$ consumption after doxorubicin administration (Table 8). We found that alterations in osmolality by glucose did not explain these observations, since when buffers of identical osmolality were used 
TABLE 6: Requirements for anthracycline-enhanced superoxide anion production by the tumor mitochondrial fraction. Superoxide formation in the tumor mitochondrial fraction was examined using paired, $1 \mathrm{ml}$ reaction mixtures containing $250 \mathrm{mM}$ sucrose, $20 \mathrm{mM}$ HEPES, pH 8.2, $100 \mu \mathrm{M}$ EDTA, $56 \mu \mathrm{M}$ acetylated cytochrome c $100 \mu \mathrm{g}$ of mitochondrial protein, and either 0 or $10 \mu \mathrm{g}$ of SOD. The reaction mixture was preincubated for $5 \mathrm{~min}$ at $37^{\circ}$ with $4 \mu \mathrm{M}$ rotenone before initiation of the reaction with $100 \mu \mathrm{M}$ NADH.

\begin{tabular}{lc}
\hline Reaction mixture & $\begin{array}{c}\text { Superoxide production } \\
(\mathrm{nmol} / \mathrm{min} / \mathrm{mg})\end{array}$ \\
\hline Control & $1.12 \pm 0.15(7)^{\mathrm{a}}$ \\
$\quad$-NADH & N.D. $(3)^{\mathrm{b}}$ \\
$\quad$-Mitochondrial fraction & N.D. $(3)$ \\
$\quad$-Rotenone & $1.02 \pm 0.01(3)$ \\
Using NADPH $(100 \mu \mathrm{M})$ & $0.77 \pm 0.26(3)$ \\
rather than NADH & $7.29 \pm 0.61(10)^{\mathrm{c}}$ \\
Doxorubicin $(135 \mu \mathrm{M})$ & $0.97 \pm 0.05(3)^{\mathrm{d}}$ \\
$\quad$-NADH & $0.61 \pm 0.20(3)^{\mathrm{d}}$ \\
$\quad$-Mitochondrial fraction & $1.28 \pm 0.56(3)^{\mathrm{d}}$ \\
Using heat-denatured & \\
mitochondria & $5.00 \pm 0.36(3)^{\mathrm{d}}$ \\
$\quad$-Rotenone & $2.76 \pm 0.44(3)^{\mathrm{d}}$ \\
Using NADPH $(100 \mu \mathrm{M})$ & $\mathrm{N} . \mathrm{D} .(3)^{\mathrm{d}}$ \\
rather than NADH & $5.51 \pm 1.22(3)$ \\
$\quad$-Acetylated cytochrome c & $5.10 \pm 0.61(3)$ \\
$\quad$-EDTA & $6.38 \pm 1.63(3)^{\mathrm{c}}$ \\
Using heat-denatured SOD & $5.71 \pm 1.02(3)^{\mathrm{c}}$ \\
Daunorubicin $(135 \mu \mathrm{M})$ & $3.32 \pm 0.31(3)^{\mathrm{c}}$ \\
Rubidazone $(135 \mu \mathrm{M})$ & $0.51 \pm 0.15(3)$ \\
Aclacinomycin A $(135 \mu \mathrm{M})$ & 5-Iminodaunorubicin \\
(135 $\mu$ M) & \\
\hline
\end{tabular}

${ }^{\mathrm{a}}$ Mean \pm S.E.; numbers in parentheses are numbers of experiments; ${ }^{\mathrm{b}}$ N.D. is not detectable; ${ }^{c}$ significantly different from control $(P<0.01)$; ${ }^{\mathrm{d}}$ significantly different from complete system containing doxorubicin alone $(P<0.01)$.

(with or without glucose), the rate of $\mathrm{O}_{2}$ consumption was significantly higher only in the presence of glucose (data not shown). As shown in Figure 2, cyanide-resistant respiration in the presence or absence of doxorubicin varied with the number of cells used in the experiment; however, the rate of oxygen consumption was always significantly higher $(P<0.01)$ when the drug was present. Finally, when experiments identical to those in Table 8 were performed with P388 murine leukemia cells treated with $\mathrm{KCN}$, we found that doxorubicin $(400 \mu \mathrm{M})$ increased $\mathrm{O}_{2}$ consumption from (mean \pm S.E.; $n=3$ ) the $0.31 \pm 0.05$ control rate to $1.15 \pm$ $0.08 \mathrm{nmol} / \mathrm{min} / 5 \times 10^{6}$ cells, $P<0.01$. Taken together, these experiments suggest that anthracycline antibiotics enhance oxy-radical production by tumor cells in a process that requires an intact quinone ring and may be modulated by the supply of cellular reducing equivalents. These features are similar to those previously described for the tumor cell organelles examined in this study; they reveal, further, that
TABLE 7: Requirements for anthracycline-stimulated superoxide formation by the nuclear fraction. Superoxide formation by tumor nuclei was examined using paired $1 \mathrm{ml}$ reaction mixtures containing $250 \mathrm{mM}$ sucrose, $20 \mathrm{mM}$ HEPES, pH 7.4, $100 \mu \mathrm{M}$ EDTA, $56 \mu \mathrm{M}$ acetylated cytochrome c, $200 \mu \mathrm{g}$ of nuclear protein, and either 0 or $10 \mu \mathrm{g}$ of SOD. The reaction was carried out at $37^{\circ} \mathrm{C}$ and was initiated by the addition of $1 \mathrm{mM}$ NADPH after the chemotherapeutic agent was added.

\begin{tabular}{lc}
\hline Reaction mixture & $\begin{array}{c}\text { Superoxide formation } \\
(\mathrm{nmol} / \mathrm{min} / \mathrm{mg})\end{array}$ \\
\hline Control & $0.36 \pm 0.05(7)^{\mathrm{a}}$ \\
Using NADH $(1 \mathrm{mM})$ & $0.28 \pm 0.08(3)$ \\
rather than NADPH & $3.29 \pm 0.33(12)^{\mathrm{b}}$ \\
Doxorubicin $(135 \mu \mathrm{M})$ & N.D. $(3)^{\mathrm{c}, \mathrm{d}}$ \\
$\quad$-NADPH & N.D. $(3)^{\mathrm{d}}$ \\
$\quad$-Acetylated cytochrome c & N.D. $(3)^{\mathrm{d}}$ \\
Using heat-denatured nuclei & $0.31 \pm 0.15(3)^{\mathrm{d}}$ \\
Using NADH $(1 \mathrm{mM})$ & $2.73 \pm 0.31(3)$ \\
rather than NADPH & $4.21 \pm 0.13(3)$ \\
$\quad+$ Heat-denatured SOD & $3.70 \pm 0.13(3)$ \\
$\quad+D M S O ~(13 \mathrm{mM})$ & N.D. $(3)^{\mathrm{d}}$ \\
$\quad+$ Catalase $(1500 \mathrm{units} / \mathrm{ml})$ & \\
Using FAD $(1 \mathrm{mM})$ rather than & N.D. $(3)^{\mathrm{d}}$ \\
NADPH & $6.63 \pm 0.64(3)^{\mathrm{b}}$ \\
Using FMN $(1 \mathrm{mM})$ rather than & $3.01 \pm 0.31(3)^{\mathrm{b}}$ \\
NADPH & $5.53 \pm 0.38(3)^{\mathrm{b}}$ \\
Daunorubicin $(135 \mu \mathrm{M})$ & \\
Rubidazone $(135 \mu \mathrm{M})$ & \\
Aclacinomycin A $(135 \mu \mathrm{M})$ &
\end{tabular}

${ }^{\mathrm{a}}$ Mean \pm S.E.; numbers in parentheses are numbers of experiments; ${ }^{b}$ significantly different from control $(P<0.01) ;{ }^{c}$ N.D. is not detectable; ${ }^{\mathrm{d}}$ significantly different from complete system containing doxorubicin alone $(P<0.01)$.

anthracycline redox cycling may overcome the ability of intact tumor cells to detoxify ROS.

As shown in Figure 1(d), the addition of cytochrome c or catalase to Ehrlich cells treated with doxorubicin $(400 \mu \mathrm{M})$ led to the release of oxygen in this closed system, indicating that $\mathrm{H}_{2} \mathrm{O}_{2}$ had been formed. We found that in the presence of doxorubicin $(400 \mu \mathrm{M})$, Ehrlich cells produced $0.64 \pm 0.04 \mathrm{nmol} \mathrm{H}_{2} \mathrm{O}_{2} / \mathrm{min} / 10^{7}$ cells compared to undetectable levels of hydrogen peroxide in the absence of the drug, $P<0.01, n=3$. Because the tumor cell outer membrane is impermeable to high molecular weight proteins such as catalase, this estimate of $\mathrm{H}_{2} \mathrm{O}_{2}$ formation probably reflects only the proportion of the total $\mathrm{H}_{2} \mathrm{O}_{2}$ pool present extracellularly; thus, it is not possible to make a direct stoichiometric comparison between total cyanideresistant $\mathrm{O}_{2}$ consumption and $\mathrm{H}_{2} \mathrm{O}_{2}$ formation, even under identical experimental conditions.

Oxy-radical cascades, which include the production of $\mathrm{H}_{2} \mathrm{O}_{2}$, may also be capable of supporting the formation of the potent oxidizing radical $\mathrm{OH}$, or a related molecule with similar chemical reactivity [33]. We investigated the mechanism of hydroxyl radical formation by Ehrlich tumor cells after treatment with doxorubicin by quantitation of the 
TABLE 8: Effect of anthracycline antibiotics on oxygen consumption by Ehrlich tumor cells. Oxygen consumption by Ehrlich cells was examined at $37^{\circ} \mathrm{C}$ as described in Materials and Methods; the total $3 \mathrm{ml}$ volume contained $1.5 \times 10^{7}$ tumor cells and the final $\mathrm{KCN}$ concentration, where used, was $2 \mathrm{mM}$.

\begin{tabular}{|c|c|c|}
\hline \multirow{2}{*}{ Reaction system } & \multicolumn{2}{|c|}{ Oxygen consumption $\left(\mathrm{nmol} \mathrm{O} / \mathrm{min} / 5 \times 10^{6}\right.$ cells $)$} \\
\hline & $+\mathrm{KCN}$ & $-\mathrm{KCN}$ \\
\hline Control & $0.54 \pm 0.04^{\mathrm{a}}$ & $9.37 \pm 0.52$ \\
\hline$+\mathrm{BCNU}(100 \mu \mathrm{g} / \mathrm{ml})$ & $0.58 \pm 0.08$ & $9.56 \pm 0.80$ \\
\hline +Glucose (10 mM) & $0.58 \pm 0.10$ & $9.67 \pm 0.90$ \\
\hline+ Antimycin $\mathrm{A}(10 \mu \mathrm{g} / \mathrm{ml})$ replacing $\mathrm{KCN}$ & $0.50 \pm 0.10$ & \\
\hline -Cells & N.D. ${ }^{b}$ & \\
\hline Doxorubicin $(90 \mu \mathrm{M})$ & $0.86 \pm 0.02^{\mathrm{c}}$ & $10.00 \pm 1.20$ \\
\hline Doxorubicin $(200 \mu \mathrm{M})$ & $1.04 \pm 0.12^{\mathrm{c}}$ & $11.46 \pm 1.18$ \\
\hline Doxorubicin $(400 \mu \mathrm{M})$ & $1.13 \pm 0.04^{\mathrm{c}}$ & $8.82 \pm 0.22$ \\
\hline$+\mathrm{BCNU}(100 \mu \mathrm{g} / \mathrm{ml})$ & $1.39 \pm 0.08^{\mathrm{d}}$ & - \\
\hline +Adenosine $(1 \mathrm{mM})$ & $1.06 \pm 0.04$ & - \\
\hline+ Glucose $(10 \mathrm{mM})$ & $1.61 \pm 0.08^{\mathrm{d}}$ & $9.47 \pm 0.16$ \\
\hline+ Antimycin A $(10 \mu \mathrm{g} / \mathrm{ml})$ replacing $\mathrm{KCN}$ & $1.19 \pm 0.04^{\mathrm{c}}$ & - \\
\hline -Cells & N.D. & - \\
\hline Doxorubicin $(1 \mathrm{mM})$ & $4.54 \pm 0.40^{\mathrm{c}}$ & - \\
\hline Daunorubicin $(400 \mu \mathrm{M})$ & $1.39 \pm 0.06^{\mathrm{c}}$ & - \\
\hline 5-Iminodaunorubicin $(400 \mu \mathrm{M})$ & $0.64 \pm 0.06$ & - \\
\hline
\end{tabular}

${ }^{\mathrm{a}}$ Mean \pm S.E. of 3 to 15 experiments; ${ }^{\mathrm{b}}$ N.D. is not detectable; ${ }^{\mathrm{c}}$ significantly different from control, at $P<0.01$; $^{\mathrm{d}}$ significantly different from samples containing doxorubicin alone, at $P<0.01$.

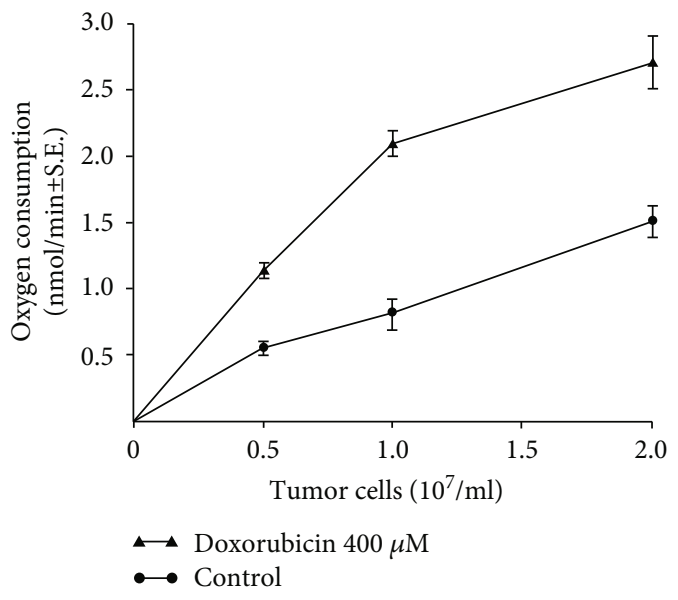

Figure 2: Effect of tumor cell number on the rate of cyanideresistant oxygen consumption in the presence and absence of doxorubicin. The doxorubicin concentration used for these experiments was $400 \mu \mathrm{M}$. These studies were performed as described in Table 8 ; the data represent the mean \pm S.E. of 3 determinations at each tumor cell concentration.

formaldehyde produced in the reaction of DMSO with $\mathrm{OH}$. As previously demonstrated, on a molar basis, formaldehyde is the major by-product of this reaction between the reactive oxygen metabolite and DMSO [24]. We maximized the possibility of measuring drug-enhanced $\mathrm{OH}$ production in these experiments by utilizing a nonionic detergent to increase the access of both doxorubicin and pyridine nucleotide cofactors to intracellular or membrane-bound dehydrogenases. The requirements for formaldehyde production by Ehrlich carcinoma cells are shown in Table 9; the hydroxyl radical was detected in this system only in the presence of the anthracycline antibiotic. Furthermore, drug-stimulated formaldehyde production was measured only when the tumor cells, DMSO, iron-EDTA, and Triton X-100 were all present in these experiments. Increasing the $\mathrm{FeSO}_{4}$ concentration above $50 \mu \mathrm{M}$ did not enhance formaldehyde production further (data not shown); whereas, $\mathrm{FeSO}_{4}$ levels as low as $1 \mu \mathrm{M}$ still supported substantial formaldehyde formation (Table 9). Furthermore, $\mathrm{FeCl}_{3}$ at a concentration of $50 \mu \mathrm{M}$ was also capable of supporting doxorubicin-enhanced formaldehyde production by Ehrlich cells; thus, both ferric and ferrous iron may serve as catalysts for this process (Table 9). In these studies, both NADPH and NADH, but not succinate, could provide the reducing equivalents necessary for oxygen radical metabolism in Ehrlich cells treated with doxorubicin. These cofactor requirements are consistent with the previously presented experiments demonstrating that the microsomal, mitochondrial, and nuclear fractions from Ehrlich cells contain different NADPH- and NADH-dependent dehydrogenases capable of catalyzing the reduction of doxorubicin to its semiquinone free radical intermediate [34-37].

Following the determination that doxorubicin could stimulate formaldehyde production from DMSO by Ehrlich cells, we examined several characteristics of ${ }^{\circ} \mathrm{OH}$ formation in this system. As shown in Figure 3(a), formaldehyde production by the carcinoma cells varied with the concentration of tumor cells used in the assay; at a doxorubicin level of 
TABLE 9: Requirements for doxorubicin-stimulated hydroxyl radical formation by detergent-treated Ehrlich carcinoma cells. Hydroxyl radical production by Ehrlich carcinoma cells was determined by measurements of formaldehyde production from DMSO; the standard reaction mixture contained $100 \mathrm{mM}$ DMSO, $100 \mu \mathrm{M}$ EDTA, $50 \mu \mathrm{M} \mathrm{FeS0}, 1 \mathrm{mM}$ NADPH, $0.1 \%$ Triton X-100, $10^{7}$ tumor cells $/ \mathrm{ml}$, and the indicated concentration of doxorubicin in a final volume of $7 \mathrm{ml}$ of PBS at pH 7.2. Data are expressed as the mean \pm S.E. of formaldehyde production for the $2 \mathrm{hr}$ reaction interval in each experimental group; the total number of experiments for each group $(n)$ is given in parentheses.

\begin{tabular}{|c|c|}
\hline Experimental system & $\begin{array}{l}\text { Hydroxyl radical production (nmol } \\
\text { formaldehyde } / 10^{7} \text { cells) }\end{array}$ \\
\hline Control & $0.0 \pm 0.0(n=5)^{\mathrm{a}}$ \\
\hline Doxorubicin $(250 \mu \mathrm{M})$ & $71.4 \pm 10.4(n=15)^{\mathrm{b}}$ \\
\hline Minus cells & $0.0 \pm 0.0(n=3)^{\mathrm{c}}$ \\
\hline Heat denatured cells ${ }^{\mathrm{d}}$ & $0.0 \pm 0.0(n=3)^{\mathrm{c}}$ \\
\hline Minus DMSO & $0.0 \pm 0.0(n=3)^{c}$ \\
\hline Minus EDTA & $0.0 \pm 0.0(n=3)^{\mathrm{c}}$ \\
\hline Minus $\mathrm{FeSO}_{4}$ & $0.0 \pm 0.0(n=3)^{\mathrm{c}}$ \\
\hline $\begin{array}{l}\text { Using } 1 \mu \mathrm{M} \text { rather than } \\
50 \mu \mathrm{M} \mathrm{FeSO}_{4}\end{array}$ & $13.2 \pm 4.6(n=3)^{\mathrm{c}}$ \\
\hline $\begin{array}{l}\text { Using } \mathrm{FeC} 13(50 \mu \mathrm{M}) \\
\text { rather than } \mathrm{FeSO}_{4}\end{array}$ & $30.9 \pm 10.0(n=3)^{\mathrm{b}}$ \\
\hline Minus NADPH & $0.0 \pm 0.0(n=3)^{\mathrm{c}}$ \\
\hline $\begin{array}{l}\text { Minus NADPH plus } \\
\text { NADH ( } 1 \mathrm{mM})\end{array}$ & $30.6 \pm 8.3(n=5)^{\mathrm{e}}$ \\
\hline $\begin{array}{l}\text { Minus NADPH plus } \\
\text { succinate }(5 \mathrm{mM})\end{array}$ & $0.0 \pm 0.0(n=3)^{\mathrm{c}}$ \\
\hline Minus Triton X-100 & $0.0 \pm 0.0(n=3)^{\mathrm{c}}$ \\
\hline
\end{tabular}

${ }^{a}$ Mean \pm S.E.; ${ }^{b}$ significantly different from the control group $(P<0.001)$; ${ }^{c}$ significantly different from complete reaction mixture containing doxorubicin and $50 \mu \mathrm{M} \mathrm{FeSO}{ }_{4}(P<0.001)$; ${ }^{d}$ tumor cells autoclaved for $60 \mathrm{~min}$; ${ }^{\mathrm{e}}$ significantly different from control and from complete reaction mixture containing NADPH $(P<0.01)$.

$250 \mu \mathrm{M}$, using a $60 \mathrm{~min}$ incubation time, peak formaldehyde production (mean \pm S.E.; $n=3 ; 69.5 \pm 6 \mathrm{nmol}$ ) occurred with $10^{7}$ tumor cells $/ \mathrm{ml}$ in the reaction mixture. We found that under similar experimental conditions, the amount of formaldehyde produced was also related to the concentration of DMSO used for the study; formaldehyde formation (mean \pm S.E., $n=3$ ) increased from $33.2 \pm 6.1 \mathrm{nmol} / 60$ $\mathrm{min} / 10^{7}$ cells to $37.1 \pm 7.2,56.9 \pm 3.4,59.7 \pm 26.1$, and $47.1 \pm 6.3$ when the DMSO concentration varied from 5 to $50,100,200$, or $1000 \mathrm{mM}$. Thus, a DMSO concentration of $100 \mathrm{mM}$ was chosen for all subsequent experiments. When the reaction interval was altered at a fixed dose of doxorubicin (Figure 3(b)), formaldehyde formation increased from undetectable levels at the zero-time point to $90.2 \pm 16.4 \mathrm{nmol} / 10^{7}$ cells, $n=3$, at $2 \mathrm{hr}$; no further, significant increase in hydroxyl radical production could be demonstrated when the incubation time was extended for up to $4 \mathrm{hr}$ after the initiation of the reaction (Figure 3(b)).

Doxorubicin increased hydroxyl radical production by Ehrlich carcinoma cells in a dose-related fashion over a wide range of drug concentrations (Figure 3(c)). Drug-stimulated formaldehyde production under our experimental condi- tions could be reproducibly measured after treatment of the cells with a doxorubicin concentration as low as $5 \mu \mathrm{M}$ $\left(24.3 \pm 11.8 \mathrm{nmol} / 120 \mathrm{~min} / 10^{7}\right.$ cells, $\left.n=3\right)$.

To examine the mechanism of formaldehyde production and to verify that the evolution of formaldehyde from DMSO was a measurement of $\mathrm{OH}$ formation, we investigated the effect of various oxygen radical scavengers on the level of formaldehyde produced by treatment of Ehrlich cells with doxorubicin. The addition of SOD or catalase, but not the heat-inactivated enzymes, significantly decreased or abolished drug-related formaldehyde production (Table 10). These results suggested that both the superoxide anion and hydrogen peroxide were necessary for the generation of 'OH by Ehrlich carcinoma cells. We also found that sodium benzoate, mannitol, diethylurea, and dimethylthiourea, which are all potent scavengers of the hydroxyl radical [38], were between 31 and $100 \%$ effective in competing with $\mathrm{DMSO}$ for reaction with $\mathrm{OH}$. However, urea, a structurally similar but ineffective $\mathrm{OH}$ scavenger, had no significant effect on formaldehyde production from DMSO (Table 10). Furthermore, we found that treatment of the permeabilized Ehrlich cells with the $\mathrm{OH}$ scavengers outlined in Table 10 decreased the production of methane, an alternate byproduct of the reaction between $\mathrm{OH}$ and DMSO, to the same extent as that found when formaldehyde was assayed (data not shown). This suggests that the hydroxyl radical scavengers actually combined with the oxidant species formed in our experimental system rather than altering the stoichiometry of the reaction pathways involved in the degradation of DMSO by the hydroxyl radical. These results, which indicated that formaldehyde production after treatment of Ehrlich carcinoma cells with doxorubicin was dependent upon the presence of the superoxide anion, hydrogen peroxide, and an iron-EDTA complex, strongly suggest that the hydroxyl radical or a related species with similar reactivity was formed in our experiments.

3.5. Antioxidant Levels. To understand the significance of drug-stimulated oxygen radical formation in each subcellular fraction, we determined the glutathione peroxidase and SOD-specific activities associated with these fractions (Table 5). As seen in Table 5, the glutathione peroxidase activity in tumor microsomes and nuclei is approximately $10 \%$ or $5 \%$ of that in the cytosol. Since Ehrlich cells contain minimal catalase activity [39], glutathione peroxidase is the major cellular defense against hydrogen peroxide. Furthermore, the glutathione peroxidase level of tumor cytosol, while more than 20 -fold greater than tumor nuclei, is only $30 \%$ as high as the enzyme level in rat heart cytosol [4]. Although the specific activity of glutathione peroxidase in tumor mitochondria exposed to ultrasonic disruption was $26.2 \%$ of that in the cytosol, ultracentrifugation of the sonicated mitochondria produced a supernatant with essentially the same specific activity as the tumor cytosol. Thus, it seems very likely that most, if not all, of the mitochondrial glutathione peroxidase is located in the mitochondrial matrix.

As shown in Table 5, the majority of tumor cell SOD is located in the cytosol, with much smaller specific activities associated with the microsomal or nuclear fractions. 


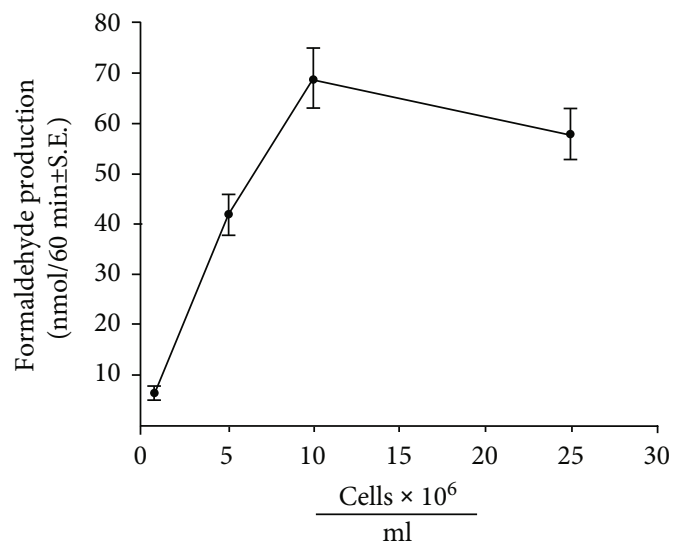

(a)

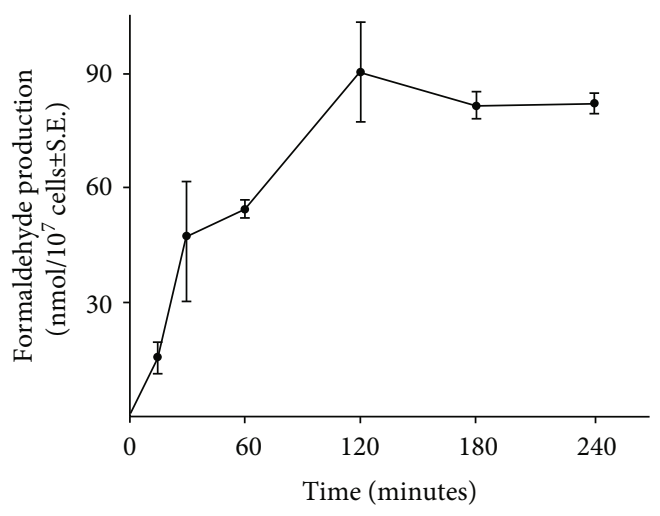

(b)

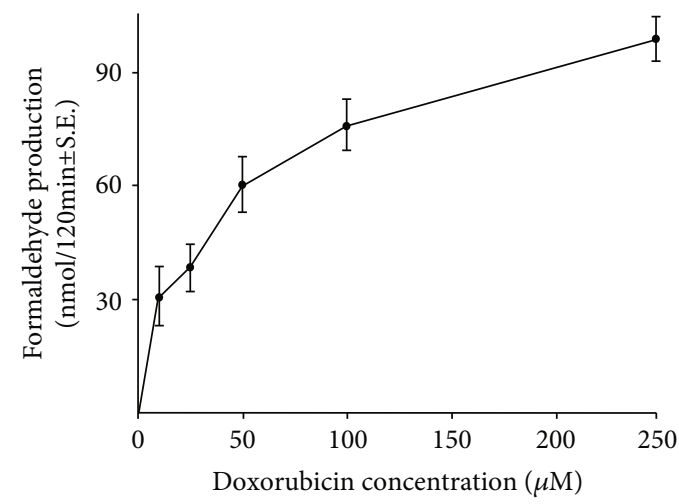

(c)

Figure 3: Effect of Ehrlich tumor cell number on doxorubicin-stimulated formaldehyde production. (a) Formaldehyde production from DMSO was assessed spectrophotometrically in the presence of a fixed concentration of doxorubicin $(250 \mu \mathrm{M})$ over a 60 min period of incubation; the data represent the mean \pm S.E. of three experiments for each concentration of tumor cells. (b) Effect of the duration of incubation on doxorubicin-induced formaldehyde formation by Ehrlich tumor cells. The extent of formaldehyde production by Ehrlich cells $\left(10^{7} / \mathrm{ml}\right)$ in the presence of doxorubicin $(250 \mu \mathrm{M})$ was determined as a function of the time after initiation of the reaction. Each time point represents the mean \pm S.E. of three experiments. (c) Effect of doxorubicin concentration on formaldehyde production by Ehrlich tumor cells. In these studies, the production of formaldehyde from DMSO was examined at a tumor cell concentration of $10^{7} / \mathrm{ml}$; the data represent the mean \pm S.E. of three experiments at each doxorubicin level tested.

Mitochondrial SOD was intermediate in specific activity between cytosol and nuclei and appeared to be present in at least two mitochondrial sites. Overall, these experiments suggest that tumor nuclei and microsomes are the least wellprotected subcellular fractions with respect to the available antioxidant defenses capable of detoxifying a drug-induced, oxy-radical cascade.

\section{Discussion}

In these experiments, we have provided a comprehensive examination of the sites and mechanisms of anthracyclinestimulated oxy-radical production by Ehrlich carcinoma cells. We found that the microsomal, mitochondrial, and nuclear tumor fractions were each capable of supporting drug-induced superoxide anion and hydrogen peroxide production under appropriate experimental conditions. For tumor microsomes and nuclei, this appeared to be an $\mathrm{NADPH}$-dependent process that resulted from reduction of the anthracycline quinone by the NADPH:cytochrome P450 reductase activity associated with either the microsomal membrane or the outer nuclear envelope. Mitochondrial anthracycline metabolism, on the other hand, was NADHdependent and was stimulated by rotenone, suggesting that an early portion of the mitochondrial NADH dehydrogenase complex was responsible for reduction of the anthracycline quinone at this intracellular location in tumor cells. Generation of ROS by anthracycline antibiotics occurred at drug concentrations that are found intracellularly following exposure of intact cells to this class of anticancer agents [40]. These experiments are among the first to demonstrate that anthracycline-related ROS production can occur at essentially every intracellular site in tumor cells leading to the formation of an extracellular, and potentially damaging, peroxide flux.

We also determined that each anthracycline tested, except for the quinone-substituted drug 5-iminodaunorubicin, was capable of enhancing oxy-radical metabolism by every subcellular fraction. Furthermore, we found that reactive oxygen metabolism occurred despite the presence of both SOD and glutathione peroxidase in the tumor organelles. Thus, if these subcellular fractions possess a similar 
TABLE 10: Effect of oxygen radical scavengers on doxorubicinenhanced formaldehyde production by detergent-treated Ehrlich tumor cells. Hydroxyl radical production by Ehrlich carcinoma cells was determined exactly as described in Table 9; data have been expressed as the mean \pm S.E. of formaldehyde production for the $2 \mathrm{hr}$ reaction interval in each experimental group, and the total number of experiments $(n)$ has been given in parentheses.

\begin{tabular}{lc}
\hline Experimental conditions & $\begin{array}{c}\text { Formaldehyde production } \\
\left(\mathrm{nmol} / 10^{7} \text { cells }\right)\end{array}$ \\
\hline $\begin{array}{l}\text { Doxorubicin }(250 \mu \mathrm{M}) \\
\text { Plus SOD }(20 \mu \mathrm{g} / \mathrm{ml})\end{array}$ & $60.4 \pm 5.6(6)^{\mathrm{a}}$ \\
$\quad \begin{array}{l}\text { Plus heat-denatured SOD } \\
(20 \mu \mathrm{g} / \mathrm{ml})^{\mathrm{c}}\end{array}$ & $49.0 \pm 9.6(6)^{\mathrm{b}}$ \\
$\begin{array}{l}\text { Plus catalase }(3000 \text { units/ml }) \\
\text { Plus heat-denatured catalase }\end{array}$ & $0.0 \pm 0.0(3)^{\mathrm{d}}$ \\
$\begin{array}{l}\text { (3000 units/ml) } \\
\text { Plus sodium benzoate } \\
(100 \mathrm{mM})\end{array}$ & $44.3 \pm 7.5(3)$ \\
Plus mannitol & $34.3 \pm 3.4(3)^{\mathrm{b}}$ \\
$\quad 100 \mathrm{mM}$ & \\
$\quad 200 \mathrm{mM}$ & $41.7 \pm 3.5(3)^{\mathrm{b}}$ \\
Plus diethylurea $(100 \mathrm{mM})$ & $23.6 \pm 3.5(3)^{\mathrm{d}}$ \\
Plus dimethylthiourea & $25.8 \pm 6.0(3)^{\mathrm{b}}$ \\
$(100 \mathrm{mM})$ & $0.0 \pm 0.0(3)^{\mathrm{d}}$ \\
Plus urea (100 mM) & $50.9 \pm 9.6(3)$
\end{tabular}

${ }^{\mathrm{a}}$ Mean \pm S.E.; ${ }^{\mathrm{b}}$ significantly different from samples treated with doxorubicin alone $(P<0.01)$; ${ }^{\mathrm{c} S O D}$ and catalase were autoclaved for $60 \mathrm{~min}$; $\mathrm{d}_{\text {significantly different from samples treated with doxorubicin alone }}$ $(P<0.001)$.

distribution of antioxidant enzymatic defenses in vivo, oxygen radical production by the anthracycline antibiotics might exceed the detoxifying capacity of various tumor cell compartments.

Using intact Ehrlich cells, the anthracycline antibiotics were shown to increase the rate of either cyanide- or antimycin A-resistant respiration. This strongly suggests that doxorubicin and other anthracycline quinones actually undergo the previously described oxidation-reduction reactions in vivo. These experiments are also important because they suggest that manipulation of the intracellular reducing environment, by glucose or by the glutathione reductase inhibitor $\mathrm{BCNU}$ (which decreases peroxide detoxification by the GSH-GSH peroxidase cycle), may affect the redox metabolism of doxorubicin in whole tumor cells.

We also determined that treatment of intact cells with doxorubicin was associated with $\mathrm{H}_{2} \mathrm{O}_{2}$ production; furthermore, our experiments suggest that following drug treatment $\mathrm{H}_{2} \mathrm{O}_{2}$ accumulates extracellularly. Thus, the plasma membrane, as well as tumor nuclei, mitochondria, and microsomes, may be at risk from a free radical attack which, in this case, could come from both inside and outside the cell. It is likely that the presence of extracellular $\mathrm{H}_{2} \mathrm{O}_{2}$ is due to either passive transport of $\mathrm{H}_{2} \mathrm{O}_{2}$, produced at several intracellular sites, across the plasma membrane or transport through an aquaporin channel [41].
As shown by our experiments with permeabilized tumor cells, under certain conditions, NA(D)PH-dependent tumor cell dehydrogenases can support a free radical cascade initiated by the anthracyclines that culminates in the formation of the hydroxyl radical. We have previously shown that hydroxyl radical-induced DNA damage occurs after doxorubicin treatment in the clinic [15]. Further, we have also reported that a wide variety of hydroxyl radical trapping agents effectively protect intact Ehrlich tumor cells against the cytotoxicity of doxorubicin as assessed by soft agar cloning techniques [13]. Because the formation of formaldehyde from DMSO in these experiments required superoxide anion, hydrogen peroxide, and iron-EDTA, it is likely that the metal-catalyzed Haber-Weiss reaction was operating under our experimental conditions [42]. This is consistent with studies indicating that iron-EDTA chelate is an especially potent redox catalyst capable of stimulating a significant degree of $\mathrm{OH}$ production in the presence of hydrogen peroxide and a reducing agent $[43,44]$. Under hypoxic conditions, the doxorubicin semiquinone may react directly with hydrogen peroxide to produce $\mathrm{OH}$ [45]; however, because our experiments were performed under highly aerobic conditions (agitation of vessels open to air in a shaking water bath), this is an unlikely explanation for the mechanism of $\mathrm{OH}$ formation in the studies presented here.

The importance of the oxidation-reduction cycle initiated by treatment of Ehrlich tumor cells with doxorubicin is related to the potent oxidizing power of various oxygen radical metabolites [46]. Thus, drug-induced oxygen radical formation could lead to the peroxidation of cellular phospholipids or the oxidation of critical sulfhydrylcontaining enzymes and structural proteins with a subsequent loss of control of divalent cation transport or membrane integrity. Furthermore, since a potential role for oxygen radicals in certain forms of DNA damage is wellestablished, it is conceivable that free radical production by Ehrlich tumor cells after treatment with doxorubicin could also contribute to previously described effects of doxorubicin on nucleic acids [47]. One or more of these consequences of drug-related oxygen radical production could contribute to the tumoricidal effect of the anthracycline antibiotics.

In summary, we propose that drug-stimulated oxygen radical metabolism by the anthracycline antibiotics in multiple tumor cell compartments may contribute significantly to the antineoplastic activity of this class of drugs.

\section{Abbreviations}

EGTA: Ethylene-glycol-bis( $\beta$-amino-ethylether)-N, N ${ }^{1}$ tetraacetic acid

HEPES: N-2-Hydroxyethylpiperazine- $\mathrm{N}^{1}$-2-ethanesulfonic acid

DTNB: 5-5' -Dithiobis(2-nitrobenzoic acid)

SOD: Superoxide dismutase

PBS: Dulbecco's phosphate buffered saline

BCNU: 1,3-Bis-chloro(2-chloroethyl)-1-nitrosourea

OH: Hydroxyl radical

ROS: Reactive oxygen species. 


\section{Data Availability}

The data used to support the findings of this study are included within the article.

\section{Conflicts of Interest}

There are no conflicts of interest associated with this paper.

\section{Acknowledgments}

This study is supported by the National Cancer Institute ZIA BC 011078 and the City of Hope National Medical Center.

\section{Supplementary Materials}

Supplementary Table 1: effect of doxorubicin on oxygen consumption by the tumor microsomal fraction. Supplementary Table 2: effect of doxorubicin on oxygen consumption by the tumor mitochondrial fraction. Supplementary Table 3: effect of alterations in NADPH:cytochrome p-450 reductase level on superoxide formation by tumor nuclei. (Supplementary Materials)

\section{References}

[1] J. H. Doroshow, "Topoisomerase II inhibitors: anthracyclines," in Cancer Chemotherapy and Biotherapy: Principles and Practice, B. A. Chabner and D. L. Longo, Eds., pp. 356-391, Lippincott, Williams, and Wilkins Publishers, 2011.

[2] S. E. Lipshultz, R. E. Scully, S. R. Lipsitz et al., "Assessment of dexrazoxane as a cardioprotectant in doxorubicin-treated children with high-risk acute lymphoblastic leukaemia: long-term follow-up of a prospective, randomised, multicentre trial," The Lancet Oncology, vol. 11, no. 10, pp. 950-961, 2010.

[3] J. Gao, Y. Xiong, Y. S. Ho et al., "Glutathione peroxidase 1deficient mice are more susceptible to doxorubicin- induced cardiotoxicity," Biochimica et Biophysica Acta (BBA) - Molecular Cell Research, vol. 1783, no. 10, pp. 2020-2029, 2008.

[4] J. H. Doroshow, "Effect of anthracycline antibiotics on oxygen radical formation in rat heart," Cancer Research, vol. 43, no. 2, pp. 460-472, 1983.

[5] J. H. Doroshow and K. J. Davies, "Redox cycling of anthracyclines by cardiac mitochondria. II. Formation of superoxide anion, hydrogen peroxide, and hydroxyl radical," The Journal of Biological Chemistry, vol. 261, no. 7, pp. 3068-3074, 1986.

[6] Y. Xiong, X. Liu, C. P. Lee, B. H. Chua, and Y. S. Ho, "Attenuation of doxorubicin-induced contractile and mitochondrial dysfunction in mouse heart by cellular glutathione peroxidase," Free Radical Biology \& Medicine, vol. 41, no. 1, pp. 46-55, 2006.

[7] C. Myers, "The role of iron in doxorubicin-induced cardiomyopathy," Seminars in Oncology, vol. 25, 4 Supplement 10, pp. 10-14, 1998.

[8] F. C. Luft, "Doxorubicin toxicity in the Iron Age," Journal of Molecular Medicine, vol. 84, no. 7, pp. 529-531, 2006.

[9] G. S. Panjrath, V. Patel, C. I. Valdiviezo, N. Narula, J. Narula, and D. Jain, "Potentiation of doxorubicin cardiotoxicity by iron loading in a rodent model," Journal of the American College of Cardiology, vol. 49, no. 25, pp. 2457-2464, 2007.
[10] B. B. Hasinoff and E. H. Herman, "Dexrazoxane: how it works in cardiac and tumor cells. Is it a prodrug or is it a drug?," Cardiovascular Toxicology, vol. 7, no. 2, pp. 140-144, 2007.

[11] X. Di, R. P. Shiu, I. F. Newsham, and D. A. Gewirtz, "Apoptosis, autophagy, accelerated senescence and reactive oxygen in the response of human breast tumor cells to adriamycin," Biochemical Pharmacology, vol. 77, no. 7, pp. 1139-1150, 2009.

[12] E. Gajewski, S. Gaur, S. A. Akman, L. Matsumoto, J. N. van Balgooy, and J. H. Doroshow, "Oxidative DNA base damage in MCF-10A breast epithelial cells at clinically achievable concentrations of doxorubicin," Biochemical Pharmacology, vol. 73, no. 12, pp. 1947-1956, 2007.

[13] J. H. Doroshow, "Role of hydrogen peroxide and hydroxyl radical formation in the killing of Ehrlich tumor cells by anticancer quinones," Proceedings of the National Academy of Sciences of the United States of America, vol. 83, no. 12, pp. 4514-4518, 1986.

[14] J. H. Doroshow and A. Juhasz, "Modulation of seleniumdependent glutathione peroxidase activity enhances doxorubicin-induced apoptosis, tumour cell killing and hydroxyl radical production in human NCI/ADR-RES cancer cells despite high-level P-glycoprotein expression," Free Radical Research, vol. 53, no. 8, pp. 882-891, 2019.

[15] J. H. Doroshow, T. W. Synold, G. Somlo, S. A. Akman, and E. Gajewski, "Oxidative DNA base modifications in peripheral blood mononuclear cells of patients treated with high-dose infusional doxorubicin," Blood, vol. 97, no. 9, pp. 2839-2845, 2001.

[16] J. M. McCord and I. Fridovich, "Superoxide dismutase. An enzymic function for erythrocuprein (hemocuprein)," The Journal of Biological Chemistry, vol. 244, no. 22, pp. 6049$6055,1969$.

[17] I. M. Goldstein, M. Brai, A. G. Osler, and G. Weissmann, "Lysosomal enzyme release from human leukocytes: mediation by the alternate pathway of complement activation," Journal of Immunology, vol. 111, pp. 33-37, 1973.

[18] R. Hinnen, H. Miyamoto, and E. Racker, " $\mathrm{Ca}^{2+}$ translocation in Ehrlich ascites tumor cells," The Journal of Membrane Biology, vol. 49, no. 4, pp. 309-324, 1979.

[19] L. A. Sordahl, C. Johnson, Z. R. Blailock, and A. Schwartz, "The mitochondrion," in Methods in Pharmacology, A. Schwartz, Ed., pp. 247-286, Appleton-Century-Crofts, New York, 1971.

[20] F. P. Mamaril, A. Dobrjansky, and S. Green, "A rapid method for the isolation of nuclei from Ehrlich ascites tumor cells," Cancer Research, vol. 30, no. 2, pp. 352-356, 1970.

[21] B. L. Horecker and A. Kornberg, "The extinction coefficients of the reduced band of pyridine nucleotides," The Journal of Biological Chemistry, vol. 175, no. 1, pp. 385-390, 1948.

[22] J. E. Biaglow and B. Jacobson, "Effect of nitrobenzene derivatives on electron transfer in cellular and chemical models," Molecular Pharmacology, vol. 13, no. 2, pp. 269282, 1977.

[23] J. B. Chappell, "The oxidation of citrate, isocitrate and cis-aconitate by isolated mitochondria," The Biochemical Journal, vol. 90, no. 2, pp. 225-237, 1964.

[24] S. M. Klein, G. Cohen, and A. I. Cederbaum, "Production of formaldehyde during metabolism of dimethyl sulfoxide by hydroxyl radical generating systems," Biochemistry, vol. 20, no. 21 , pp. 6006-6012, 1981. 
[25] T. Nash, "The colorimetric estimation of formaldehyde by means of the Hantzsch reaction," The Biochemical Journal, vol. 55, no. 3, pp. 416-421, 1953.

[26] J. H. Doroshow, G. Y. Locker, and C. E. Myers, "Enzymatic defenses of the mouse heart against reactive oxygen metabolites: alterations produced by doxorubicin," The Journal of Clinical Investigation, vol. 65, no. 1, pp. 128-135, 1980.

[27] O. H. Lowry, N. Rosebrough, A. Farr, and R. Randall, "Protein measurement with the folin phenol reagent," The Journal of Biological Chemistry, vol. 193, no. 1, pp. 265-275, 1951.

[28] P. Armitage, Statistical Methods in Medical Research, Blackwell Scientific Publications, 1971.

[29] K. J. Davies and J. H. Doroshow, "Redox cycling of anthracyclines by cardiac mitochondria. I. Anthracycline radical formation by NADH dehydrogenase," The Journal of Biological Chemistry, vol. 261, no. 7, pp. 3060-3067, 1986.

[30] K. J. Davies, J. H. Doroshow, and P. Hochstein, "Mitochondrial NADH dehydrogenase-catalyzed oxygen radical production by adriamycin, and the relative inactivity of 5iminodaunorubicin," FEBS Letters, vol. 153, no. 1, pp. 227230, 1983.

[31] C. E. Myers, J. R. Muindi, J. Zweier, and B. K. Sinha, “5-Iminodaunomycin: an anthracycline with unique properties," The Journal of Biological Chemistry, vol. 262, no. 24, pp. 1157111577, 1987.

[32] R. Bredehorst, M. Panneerselvam, and C.-W. Vogel, "Doxorubicin enhances complement susceptibility of human melanoma cells by extracellular oxygen radical formation," The Journal of Biological Chemistry, vol. 262, no. 5, pp. 20342041, 1987.

[33] R. Liu, R. K. Narla, I. Kurinov, B. Li, and F. M. Uckun, "Increased hydroxyl radical production and apoptosis in PC12 neuron cells expressing the gain-of-function mutant G93A SOD1 gene," Radiation Research, vol. 151, no. 2, pp. 133-141, 1999.

[34] O. Dionisi, T. Galeotti, T. Terranova, and A. Azzi, "Superoxide radicals and hydrogen peroxide formation in mitochondria from normal and neoplastic tissues," Biochimica et Biophysica Acta (BBA) - Enzymology, vol. 403, no. 2, pp. 292-300, 1975.

[35] K. H. Ibsen and K. W. Schiller, "Control of glycolysis and respiration in substrate-depleted Ehrlich ascites tumor cells," Archives of Biochemistry and Biophysics, vol. 143, no. 1, pp. 187-203, 1971.

[36] K. W. Bock, V. Gang, H. P. Beer, R. Kronau, and H. Grunicke, "Localization and regulation of two NAD nucleosidases in Ehrlich ascites cells," European Journal of Biochemistry, vol. 4, no. 3, pp. 357-363, 1968.

[37] G. M. Bartoli, A. Dani, T. Galeotti, M. Russo, and T. Terranova, "Respiratory activity of Ehrlich ascites tumour cell nuclei," Zeitschrift für Krebsforschung und Klinische Onkologie. Cancer Research and Clinical Oncology, vol. 83, no. 3, pp. 223-231, 1975.

[38] K. B. Adler, W. J. Holden-Stauffer, and J. E. Repine, "Oxygen metabolites stimulate release of high-molecular-weight glycoconjugates by cell and organ cultures of rodent respiratory epithelium via an arachidonic acid-dependent mechanism," The Journal of Clinical Investigation, vol. 85, no. 1, pp. 75-85, 1990.

[39] A. Bozzi, I. Mavelli, A. Finazzi Agrò et al., "Enzyme defense against reactive oxygen derivatives. II. Erythrocytes and tumor cells," Molecular and Cellular Biochemistry, vol. 10, no. 1, pp. 11-16, 1976.
[40] B. A. Johnson, M. S. Cheang, and G. J. Goldenberg, "Comparison of adriamycin uptake in chick embryo heart and liver cells an murine L5178Y lymphoblasts in vitro: role of drug uptake in cardiotoxicity," Cancer Research, vol. 46, no. 1, pp. 218 223, 1986.

[41] J. R. Thiagarajah, J. Chang, J. A. Goettel, A. S. Verkman, and W. I. Lencer, "Aquaporin-3 mediates hydrogen peroxidedependent responses to environmental stress in colonic epithelia," Proceedings of the National Academy of Sciences of the United States of America, vol. 114, no. 3, pp. 568-573, 2017.

[42] P. E. Starke and J. L. Farber, "Ferric iron and superoxide ions are required for the killing of cultured hepatocytes by hydrogen peroxide: evidence for the participation of hydroxyl radicals formed by an iron-catalyzed Haber-Weiss reaction," The Journal of Biological Chemistry, vol. 260, no. 18, pp. 10099-10104, 1985.

[43] M. F. McCarty and F. Contreras, "Increasing superoxide production and the labile iron pool in tumor cells may sensitize them to extracellular ascorbate," Frontiers in Oncology, vol. 4, p. 249, 2014.

[44] G. F. Vile, C. C. Winterbourn, and H. C. Sutton, "Radicaldriven Fenton reactions: studies with paraquat, adriamycin, and anthraquinone 6-sulfonate and citrate, ATP, ADP, and pyrophosphate iron chelates," Archives of Biochemistry and Biophysics, vol. 259, no. 2, pp. 616-626, 1987.

[45] C. C. Winterbourn, "Evidence for the production of hydroxyl radicals from the adriamycin semiquinone and $\mathrm{H}_{2} \mathrm{O}_{2}$," FEBS Letters, vol. 136, no. 1, pp. 89-94, 1981.

[46] G. Vile and C. Winterbourn, "Thiol oxidation and inhibition of Ca-ATPase by adriamycin in rabbit heart microsomes," Biochemical Pharmacology, vol. 39, no. 4, pp. 769-774, 1990.

[47] S. A. Akman, J. H. Doroshow, T. G. Burke, and M. Dizdaroglu, "DNA base modifications induced in isolated human chromatin by NADH dehydrogenase-catalyzed reduction of doxorubicin," Biochemistry, vol. 31, no. 13, pp. 3500-3506, 1992.

[48] L. B. Sheiner, "ELSFIT: a program for the extended least squares fit to individual pharmacokinetic data," in San Francisco: Division of Clinical Pharmacology, pp. 1-82, University of California, 1981. 


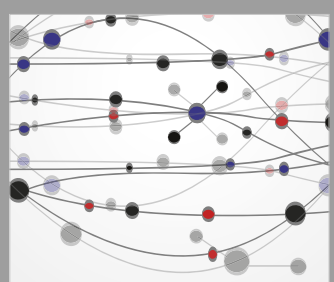

The Scientific World Journal
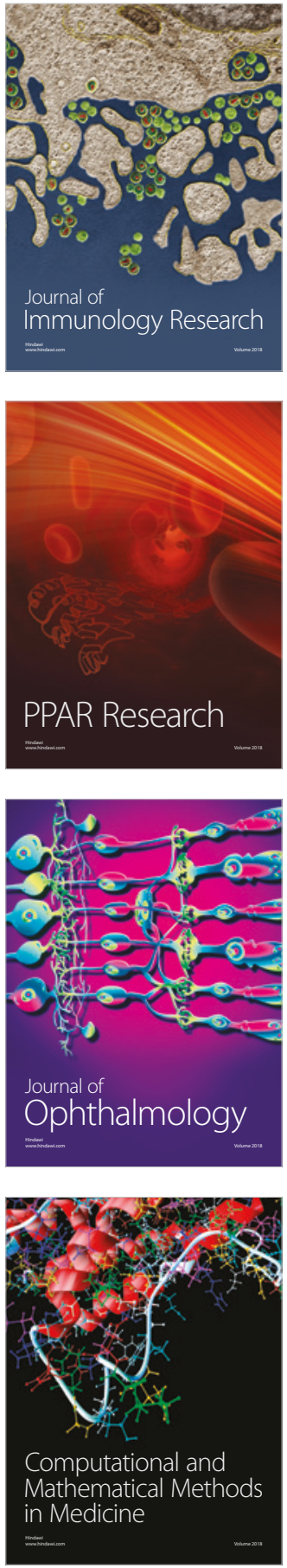

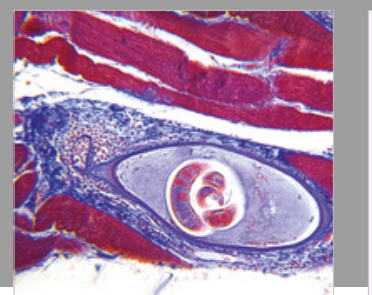

Gastroenterology Research and Practice

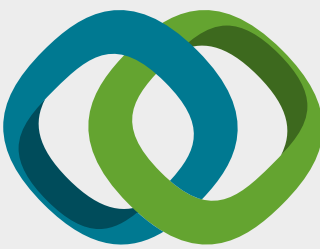

\section{Hindawi}

Submit your manuscripts at

www.hindawi.com
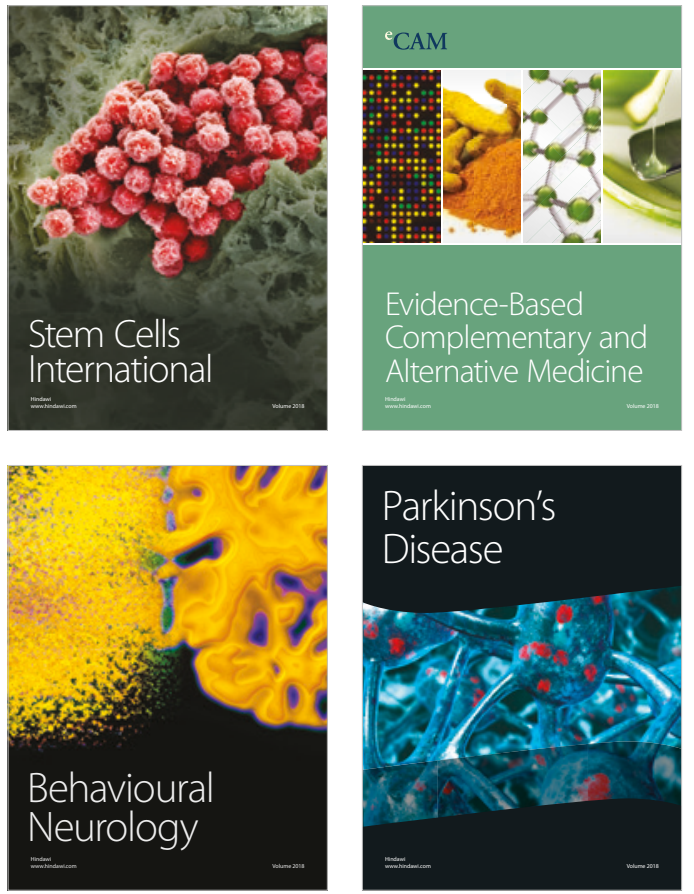

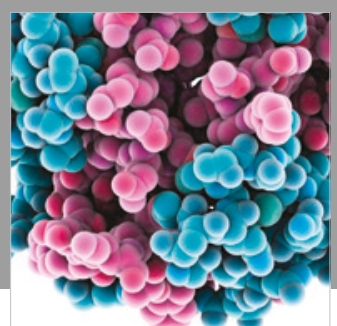

ournal of

Diabetes Research

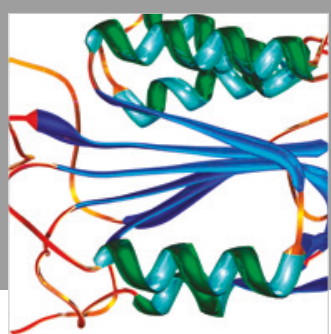

Disease Markers
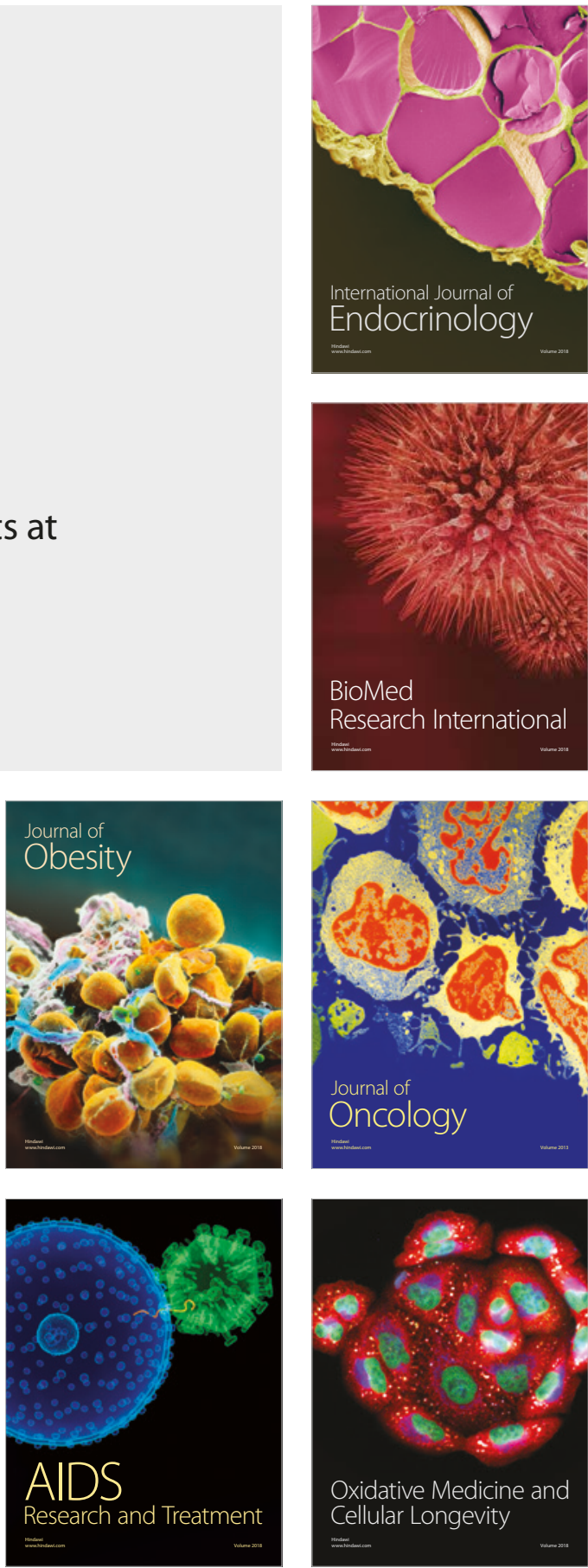